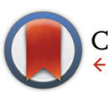

CrossMark \& click for updates

Cite this: Org. Biomol. Chem., 2016, 14,1794

Received 2nd December 2015, Accepted 5th January 2016

DOI: $10.1039 / c 5 o b 02467 f$

www.rsc.org/obc

\section{Synthesis, structure and pyrolysis of stabilised phosphonium ylides containing saturated oxygen heterocycles $\dagger$}

\author{
R. Alan Aitken, ${ }^{\star a}$ Nazira Karodia, ${ }^{\star b}{ }^{\mathrm{b}}$ Hollie B. McCarron, ${ }^{a}$ Cécile Rouxel, ${ }^{a}$ \\ Nina Sahabo ${ }^{b}$ and Alexandra M. Z. Slawin ${ }^{a}$
}

\begin{abstract}
A range of twelve stabilised phosphonium ylides containing tetrahydrofuran, tetrahydropyran or 2,2dimethyl-1,3-dioxolane rings have been prepared and fully characterised, including one X-ray structure determination of each type. The $\mathrm{X}$-ray structures confirm the $\mathrm{P}=\mathrm{C}$ and $\mathrm{C}=\mathrm{O}$ functions to be syn and all the compounds undergo thermal extrusion of $\mathrm{Ph}_{3} \mathrm{PO}$ to give the corresponding alkynes. In some cases there is also competing loss of $\mathrm{Ph}_{3} \mathrm{P}$ to give different carbene-derived products and evidence has been obtained for the generation of 2-phenyloxete in this way. Raising the pyrolysis temperature leads in several cases to new secondary reactions of the alkyne products involving a sequence of alkyne to vinylidene isomerisation, intramolecular $\mathrm{CH}$ insertion, and retro Diels Alder reaction.
\end{abstract}

\section{Introduction}

Thermal extrusion of $\mathrm{Ph}_{3} \mathrm{PO}$ from suitably substituted $\beta$-oxophosphonium ylides in the so-called "intramolecular Wittig reaction" is a versatile method of alkyne synthesis. ${ }^{1}$ The ylides are readily prepared in a few simple steps from alkyl halides and acid chlorides as stable crystalline solids, and overall this represents an unusual way to construct the alkyne triple bond (Scheme 1). The process was first described in 1959 for $\mathrm{R}^{1}=\mathrm{R}^{2}$ $=\mathrm{Ph}$ where simply heating the ylide at $300{ }^{\circ} \mathrm{C}$ resulted in the desired elimination of $\mathrm{Ph}_{3} \mathrm{PO}$ to give diphenylacetylene in 59\% yield. ${ }^{2}$ Shortly thereafter a convenient synthesis of acetylenic esters by pyrolysis of the ylides with $\mathrm{R}^{1}=\mathrm{CO}_{2}$ Me was reported. ${ }^{3}$ Over the next 25 years many further examples appeared, but using conventional pyrolysis the scope was limited to examples where $\mathrm{R}^{1}$ was an electron withdrawing group. ${ }^{4}$ This restriction was overcome by the use of flash vacuum pyrolysis (FVP) which allowed synthesis of purely aliphatic and terminal alkynes from ylides with $\mathrm{R}^{1}=$ alkyl or $\mathrm{H}^{5}{ }^{5}$ Using this method, a wide range of functionalised alkynes have been prepared and typical examples include the synthesis of fused ring heterocycles via cascade cyclisation ${ }^{6,7}$ and chiral amino acid-derived

\footnotetext{
${ }^{a}$ EaStCHEM School of Chemistry, University of St Andrews, St Andrews, Fife, KY16 9ST, UK. E-mail: raa@st-and.ac.uk

${ }^{b}$ School of Life Sciences, University of Bradford, Bradford, W Yorkshire, BD7 1DP, UK $\dagger$ Electronic supplementary information (ESI) available: Copies of ${ }^{1} \mathrm{H}$ and ${ }^{13} \mathrm{C}$ NMR spectra of all compounds. CCDC 1435297-1435299. For ESI and crystallographic data in CIF or other electronic format see DOI: 10.1039/c5ob02467f $\$$ Present address: School of Biology, Chemistry and Forensic Science, University of Wolverhampton, Wulfruna Street, Wolverhampton, WV1 1LY, UK. E-mail: nazira.karodia@wlv.ac.uk
}

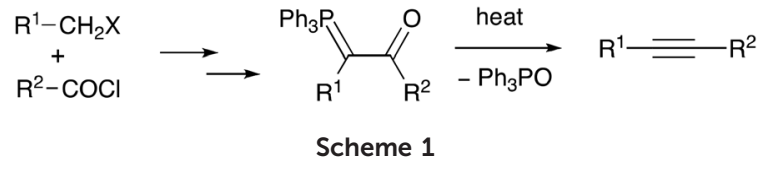

alkynes. ${ }^{8}$ FVP is a technique of increasing importance in the synthesis of heterocyclic compounds, ${ }^{9}$ but has not so far seen any significant application in carbohydrate chemistry. In fact the use of FVP in carbohydrate chemistry is effectively limited to a single example: the pyrolytic elimination of acetic acid to form a derivative of zanamivir (Relenza). ${ }^{10}$ In this paper we describe the preparation and pyrolysis behaviour of a series of ylides containing tetrahydrofuran, tetrahydropyran and 2,2dimethyl-1,3-dioxolane rings to check the compatibility of these ring systems common in carbohydrates with the conditions required for alkyne formation. There has been considerable interest in acetylenic carbohydrate derivatives, both in their own right, ${ }^{11}$ and as intermediates in synthesis of modified nucleosides. ${ }^{12,13}$ Alkyne-containing 2,2-dimethyl-1,3dioxolanes have also found use in total synthesis. ${ }^{14,15}$ There is a single previous example of this approach in which a tetrahydropyran-containing ylide $\mathbf{1}$ was prepared and subjected to conventional pyrolysis at $200-250{ }^{\circ} \mathrm{C}$ (heating the solid above its mp) to afford alkyne 2 in $75 \%$ yield (Scheme 2). ${ }^{16}$

\section{Results and discussion}

The ylides 4 were prepared by two different methods depending on the nature of $\mathrm{R}^{1}$ (Scheme 3). For monostabilised ylides 
<smiles>CCOC(=O)C(=P)C1CCOC(C)(C)C1</smiles>

1

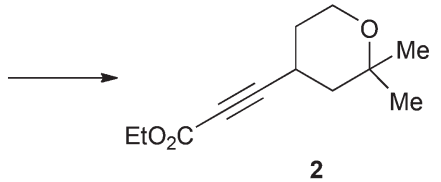

Scheme 2

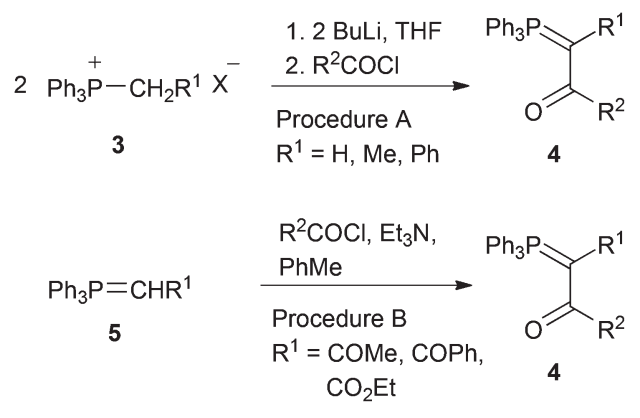<smiles>CC(C)(C)CCCCC(=O)C(=CPc1ccccc1)C1CCCO1</smiles><smiles>CC(=P)C(=O)C1CCCO1</smiles><smiles>CC(C)CCCC(=O)C(=Pc1ccccc1)C1CCCO1</smiles><smiles>CC(=O)C(=Pc1ccccc1)C(=O)C1CCCO1</smiles>
$977 \%$<smiles>O=C(C=[PH2]P)C1CCOCC1</smiles>
12 23\%<smiles>CCOC(=P)C(=P)C(=O)C1CCOCC1</smiles>
$1566 \%$<smiles>O=C(C(=Pc1ccccc1)C(=O)C1CCCO1)c1ccccc1</smiles>

$1024 \%$<smiles>CC(=Pc1ccccc1)C(=O)C1CCOCC1</smiles>
$1326 \%$<smiles>CC1(C)OCC(C(=O)C(=P)c2ccccc2)O1</smiles>

$1625 \%$<smiles>CCOC(=P)C(=P)C(=O)C1CCCO1</smiles>

$1125 \%$<smiles>O=C(C(=P)c1ccccc1)C1CCOCC1</smiles>

$146 \%$<smiles>CCOC(=P)C(=O)C1COC(C)(C)O1</smiles>

Scheme 3 Synthetic routes used and new ylides prepared.

$\left(\mathrm{R}^{1}=\mathrm{H}, \mathrm{Me}, \mathrm{Ph}\right)$ reaction of the appropriate phosphonium salt 3 with butyllithium in THF followed by the acid chloride proceeded with "transylidation" ${ }^{, 17}$ requiring a 2:1 reacting ratio, while for distabilised ylides $\left(\mathrm{R}^{1}=\mathrm{COMe}, \mathrm{COPh}, \mathrm{CO}_{2} \mathrm{Et}\right)$ reaction of 5 with the acid chloride and triethylamine in toluene was used. ${ }^{18}$ Tetrahydrofuran-2-carbonyl chloride was prepared by reaction of the commercially available acid with oxalyl chloride, tetrahydropyran-4-carbonyl chloride was prepared by hydrolysis of methyl tetrahydropyran-4-carboxylate using sodium hydroxide followed by reaction with thionyl chloride, while 2,2-dimethyl-1,3-dioxolane-4-carbonyl chloride was prepared from mannitol diacetonide by sodium periodate cleavage $^{19}$ followed by potassium permanganate oxidation of the resulting aldehyde and treatment of the potassium carboxylate with oxalyl chloride. ${ }^{20}$ The 12 ylides 6-17 were obtained in low to moderate yield as colourless or pale yellow crystals (Scheme 3). They all gave ${ }^{31} \mathrm{P}$ NMR chemical shifts in the range $\delta_{\mathrm{P}}+14.9-17.9$ and the ${ }^{13} \mathrm{C}$ NMR spectra showed a highly consistent and informative pattern of phosphorus coupling. X-Ray diffraction has previously been used to obtain valuable information on the structure of stabilised ylides, particularly in respect of the $\mathrm{P}=\mathrm{C}-\mathrm{C}=\mathrm{O}$ torsion angle which is important for successful pyrolytic alkyne formation. ${ }^{21}$ Since no X-ray structures of ylides containing saturated oxygen heterocycles are known, we have determined the structure of one representative example from each of the three ring systems.

The structure of compound 10 (Fig. 1) shows an almost planar tetrahydrofuran ring and both carbonyl groups syn to the $\mathrm{P}=\mathrm{C}$ bond. However the degree of delocalisation in the sense $\mathrm{P}^{+}-\mathrm{C}=\mathrm{C}-\mathrm{O}^{-}$as indicated by the $\mathrm{CC}$ and $\mathrm{CO}$ bond lengths is much greater for the CO-THF function with a torsion angle of $0.7^{\circ}$ than for the COPh with a torsion angle of $34^{\circ}$.

In the tetrahydropyran series, the structure of the monostabilised ylide $\mathbf{1 3}$ was determined (Fig. 2) and this shows the tetrahydropyran in an almost perfect chair conformation with the oxo ylide function equatorial. The bond lengths again show the oxo ylide function to be substantially delocalised in the sense $\mathrm{P}^{+}-\mathrm{C}=\mathrm{C}-\mathrm{O}^{-}$and $\mathrm{P}=\mathrm{C}$ and $\mathrm{C}=\mathrm{O}$ are syn.

The structure of $\mathbf{1 7}$ proved to be more complex with two separate and slightly different molecules in the unit cell (Fig. 3). In each case the ester carbonyl is anti to the $\mathrm{P}=\mathrm{C}$ bond while the dioxolanyl ketone is syn to it but, while the molecule containing $\mathrm{P}(41)$ has these functions almost coplanar (torsion angles 178.7 and $1.0^{\circ}$ ), the geometry for the other molecule containing $\mathrm{P}(1)$ is less ideal (torsion angles 156.8 and $10.6^{\circ}$ ).

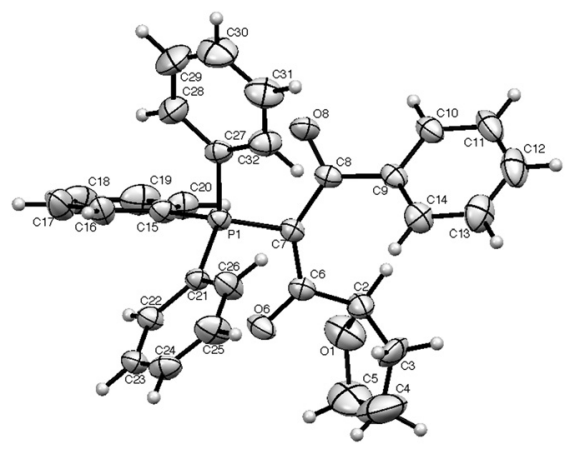

Fig. 1 X-ray structure of 10 showing numbering scheme. Selected bond lengths and torsion angles: $P(1)-C(7) 1.752(2), C(7)-C(8) 1.459(3)$, $\mathrm{C}(8)-\mathrm{O}(8) 1.232(2), \mathrm{C}(7)-\mathrm{C}(6) 1.423(3), \mathrm{C}(6)-\mathrm{O}(6) 1.240(2) \AA ;$; $(1)-\mathrm{C}(7)-$ $\mathrm{C}(8)-\mathrm{O}(8) 34.2(2), \mathrm{P}(1)-\mathrm{C}(7)-\mathrm{C}(6)-\mathrm{O}(6) 0.7(2)^{\circ}$. 


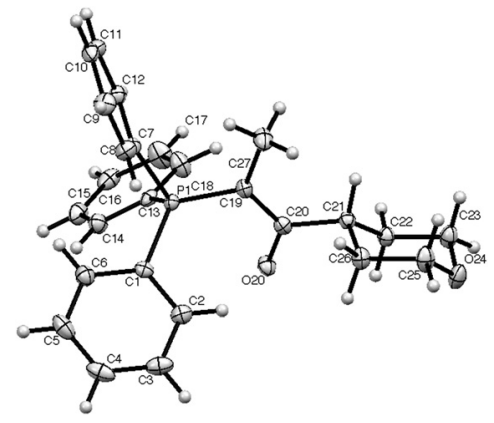

Fig. 2 X-ray structure of 13 showing numbering scheme. Selected bond lengths and torsion angle: $P(1)-C(19) 1.729(2), C(19)-C(20)$ 1.396(2), $C(20)-O(20) 1.267(2) \AA ̊ ; P(1)-C(19)-C(20)-O(20) 2.4(2)^{\circ}$.

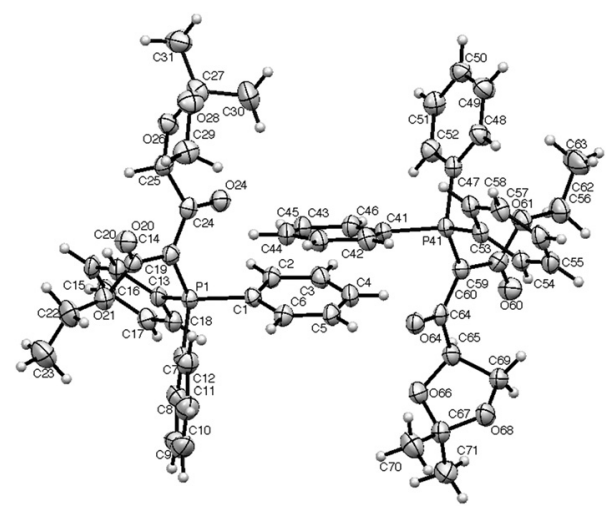

Fig. 3 X-ray structure of 17 showing numbering scheme. Selected bond lengths and torsion angles: $P(1)-C(19)$ 1.751(5), $C(19)-C(24)$ 1.434(6), $C(24)-O(24) 1.227(7), C(19)-C(20) 1.445(9), C(20)-O(20)$ 1.208(7), $P(41)-C(59) 1.760(6), \quad C(59)-C(60) 1.445(9), C(60)-O(60)$ 1.215(7), $C(59)-C(64)$ 1.444(6), $C(64)-O(64)$ 1.224(7) $\AA$; $P(1)-C(19)-$ $\mathrm{C}(24)-\mathrm{O}(24)$ 10.6(7), $\mathrm{P}(1)-\mathrm{C}(19)-\mathrm{C}(20)-\mathrm{O}(20)$ 156.8(4), $\mathrm{P}(41)-\mathrm{C}(59)-$ $C(60)-O(60) 178.7(4), P(41)-C(59)-C(64)-O(64) 1.0(7)^{\circ}$.

The behaviour of the compounds was now studied under flash vacuum pyrolysis conditions. The apparatus used has been described previously, ${ }^{22}$ and based on our extensive experience with oxo stabilised ylides, temperatures in the range $500-750{ }^{\circ} \mathrm{C}$ were used with a pressure of $1-5 \times 10^{-2}$ Torr. The two compounds with a hydrogen atom on the ylidic bond, 6 and 12, reacted completely at $750{ }^{\circ} \mathrm{C}$ with clean extrusion of $\mathrm{Ph}_{3} \mathrm{PO}$ being observed in each case (Scheme 4). For 6 the other product was the expected terminal alkyne 18 (36\%) together with a little furan and benzene from thermal degradation. In the case of the tetrahydropyran compound 12, the expected alkyne $19(42 \%)$ was again formed but this was now accompanied by low yields of cyclopentadiene and acetaldehyde. We believe these to result from the mechanism shown in Scheme 4 in which the alkyne isomerises to the vinylidene 20 and this undergoes intramolecular $\mathrm{CH}$ insertion at the 2-position of the tetrahydropyran to form the bicyclic product 21. This is then set up to undergo a retro Diels-Alder reaction with formation of cyclopentadiene and oxirane, which
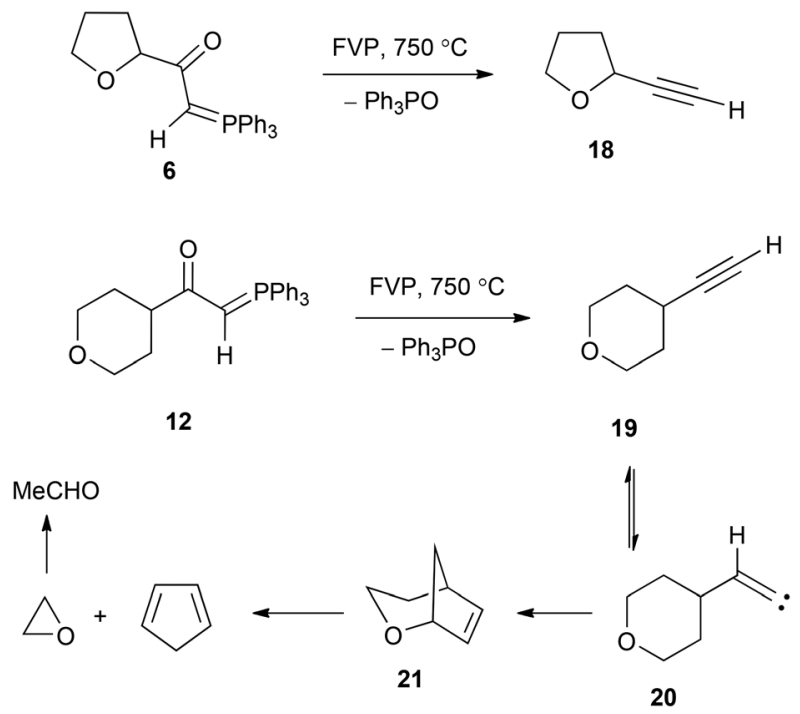

Scheme 4
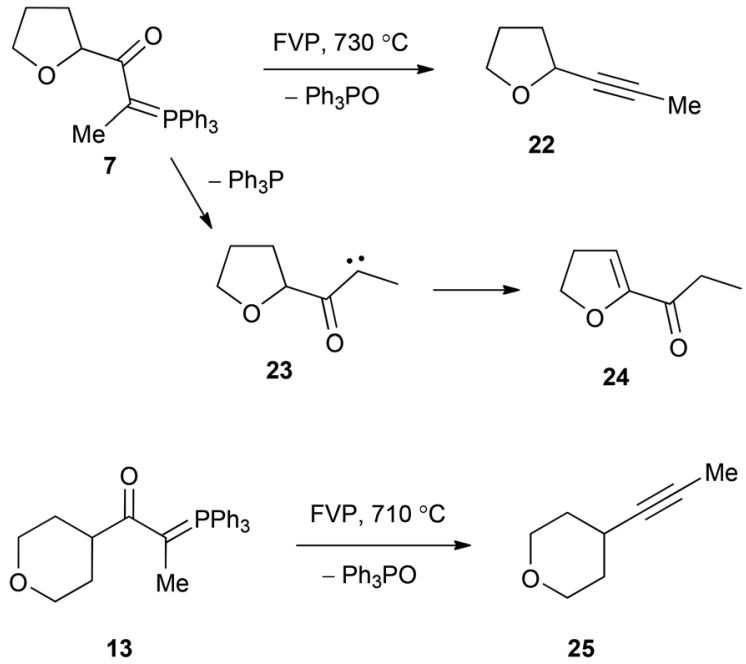

Scheme 5

isomerises to acetaldehyde. The formation of vinylidenes such as 20 by rearrangement of alkynes under FVP conditions is well known, ${ }^{23}$ and will be encountered again in the FVP of $\mathbf{9}$ and $\mathbf{1 0 .}$.

The ylide 7 with a methyl group on the ylidic position reacted completely at $730^{\circ} \mathrm{C}$ to give a $2: 1$ mixture of $\mathrm{Ph}_{3} \mathrm{P}$ and $\mathrm{Ph}_{3} \mathrm{PO}$ at the furnace exit. In the cold trap the expected alkyne $22(20 \%)$ from loss of $\mathrm{Ph}_{3} \mathrm{PO}$ was accompanied by 2-propionyl4,5-dihydrofuran 24 (30\%) (Scheme 5). We propose that this product is formed by loss of $\mathrm{Ph}_{3} \mathrm{P}$ to give the (triplet) carbene 23, which then undergoes twofold intramolecular hydrogen atom abstraction to afford the product. In contrast the corresponding tetrahydropyran ylide 13 underwent exclusive elimination of $\mathrm{Ph}_{3} \mathrm{PO}$ at $710{ }^{\circ} \mathrm{C}$ to give the expected alkyne 25 in 

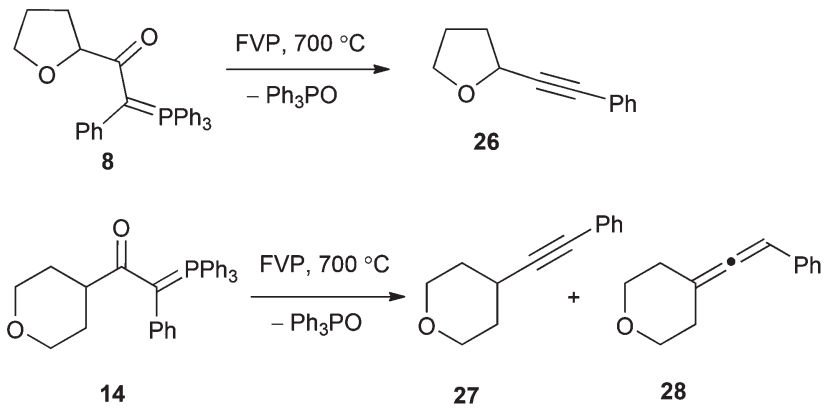

Scheme 6

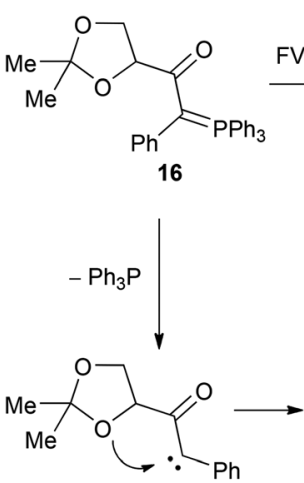

31
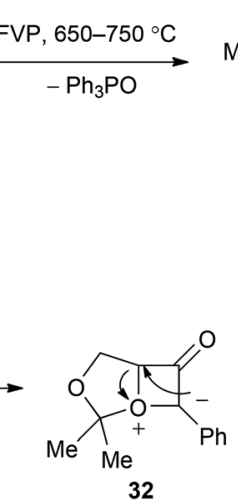

32

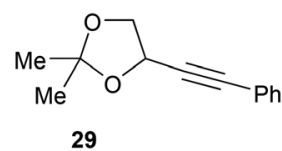

29
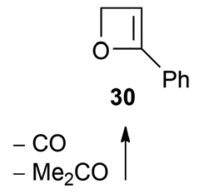

Scheme 7

good yield as the only product. The extrusion of a phosphine as opposed to phosphine oxide from $\beta$-oxophosphonium ylides is very unusual, but has been observed in the FVP of a benzotriazolyl ylide, ${ }^{24,25}$ and also upon photolysis of $\mathrm{Ph}_{3} \mathrm{P}=$ CHCOPh. $^{26}$

The two compounds $\mathbf{8}$ and $\mathbf{1 4}$ with a phenyl substituent on the ylidic carbon both reacted completely at $700{ }^{\circ} \mathrm{C}$ with exclusive elimination of $\mathrm{Ph}_{3} \mathrm{PO}$. With the tetrahydrofuran compound 8 the product was the known alkyne 26 (56\%) (Scheme 6), which showed good agreement with literature spectroscopic data, ${ }^{27,28}$ while for the tetrahydropyran compound 14, the expected alkyne product 27 (46\%) was accompanied by the isomeric allene 28 (20\%). The ylide 16 containing phenyl and 2,2-dimethyl-1,3-dioxolane groups was found to undergo loss of both $\mathrm{Ph}_{3} \mathrm{PO}$ and $\mathrm{Ph}_{3} \mathrm{P}$ to give separate products with the relative importance of the two competing pathways varying with temperature (Scheme 7). Thus at $650{ }^{\circ} \mathrm{C}$, there was predominant loss of $\mathrm{Ph}_{3} \mathrm{PO}\left(\mathrm{Ph}_{3} \mathrm{PO} / \mathrm{Ph}_{3} \mathrm{P} 8: 1\right)$ to afford the expected alkyne 29 in $48 \%$ yield readily identified by comparison with reported spectroscopic data. ${ }^{29}$ By increasing the pyrolysis temperature to $750{ }^{\circ} \mathrm{C}$ the importance of the $\mathrm{Ph}_{3} \mathrm{P}$ elimination route was increased $\left(\mathrm{Ph}_{3} \mathrm{PO} / \mathrm{Ph}_{3} \mathrm{P} 3: 1\right)$ and this allowed tentative identification of the resulting product as 2-phenyloxete 30. A correct HRMS measurement corresponding to 30 was obtained and, although peak overlap pre-

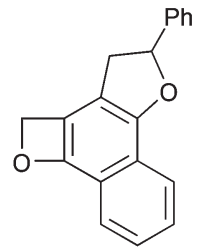

34

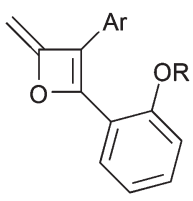

35

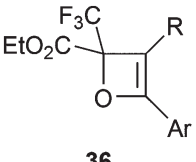

Scheme 8 Previously reported oxetes.

vented full spectroscopic characterisation, the key signals in ${ }^{1} \mathrm{H}$ and ${ }^{13} \mathrm{C}$ NMR spectra were consistent with a highly shielded (enol ether) $=\mathrm{CH}-\left[\delta_{\mathrm{H}} 6.16(1 \mathrm{H}, \mathrm{t}, J 6.9) ; \delta_{\mathrm{C}} 93.9\right]$ adjacent to a $-\mathrm{CH}_{2} \mathrm{O}-\left[\delta_{\mathrm{H}} 5.14(2 \mathrm{H}, \mathrm{d}, J 6.9) ; \delta_{\mathrm{C}} 78.7\right]$ function. The latter compares well with the value of $\delta_{\mathrm{H}} 5.44$ observed for the oxete $\mathrm{CH}_{2}$ in compound 34 (Scheme 8). ${ }^{30}$

Simple oxetes such as this are almost unknown but there has been recent interest in more highly substituted examples such as the 4-methylene compounds $\mathbf{3 5}$ obtained by gold-catalysed cyclisation of $\alpha$-hydroxybenzylallenes, ${ }^{31}$ and stable fully substituted compounds 36 prepared in high enantiomeric purity from ethyl trifluoropyruvate and alkynes. ${ }^{32}$ The parent compound has also been generated ${ }^{33}$ and was stable enough for a ${ }^{1} \mathrm{H}$ NMR spectrum to be recorded at $-25{ }^{\circ} \mathrm{C}\left[\delta_{\mathrm{H}} 6.70(1 \mathrm{H}\right.$, br s), $5.73(1 \mathrm{H}$, br s) and $5.27(2 \mathrm{H}, \mathrm{br} \mathrm{s})]$, but it isomerised to acrolein on warming to room temperature.

We rationalise the formation of 30, as shown in Scheme 7, by initial loss of $\mathrm{Ph}_{3} \mathrm{P}$ from ylide 16 to give the carbene 31 which undergoes intramolecular oxonium ylide formation to form 32. This can then rearrange as shown to give 33, which loses $\mathrm{CO}$ and acetone to afford the oxete. Further support for this route was provided by the observation of acetone among the pyrolysis products.

We next examined the two ylides $\mathbf{9}$ and $\mathbf{1 0}$ where there is potentially a choice between elimination of $\mathrm{Ph}_{3} \mathrm{PO}$ in two directions to give isomeric alkynyl ketones. In previous such cases there has been little selectivity with almost equal proportions of the two possible products being formed. ${ }^{34,35}$ This also proved to be the case here, with compound 9 undergoing complete extrusion of $\mathrm{Ph}_{3} \mathrm{PO}$ at $500{ }^{\circ} \mathrm{C}$ to afford a mixture of 37 (26\%) and 39 (58\%), while the benzoyl compound 10 gave a mixture of 38 (29\%) and 40 (30\%) under the same conditions (Scheme 9). All these alkynyl ketone products are previously unknown.

When ylides $\mathbf{9}$ and $\mathbf{1 0}$ were pyrolysed at the higher temperature of $700{ }^{\circ} \mathrm{C}$ an interesting new process was observed. In each case the previously observed alkynyl ketones were still formed but these were accompanied by the 3-acylfurans 41 and 42 , readily identified by comparison with literature spectroscopic data. ${ }^{36,37}$ Thus FVP of 9 at $700{ }^{\circ} \mathrm{C}$ gave $37(18 \%)$, 39 (33\%) and $41(17 \%)$ while under the same conditions 10 gave 38 (12\%), 40 (14\%) and 42 (37\%). As shown we propose that this involves isomerisation ${ }^{23}$ of the alkynyl ketones 39 and $\mathbf{4 0}$ to the vinylidene $\mathbf{4 3}$ which undergoes intramolecular 


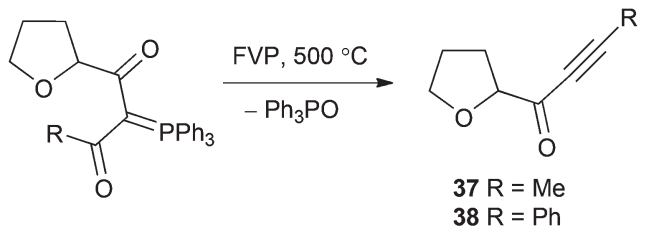

$9 \mathrm{R}=\mathrm{Me}$ $10 \mathrm{R}=\mathrm{Ph}$
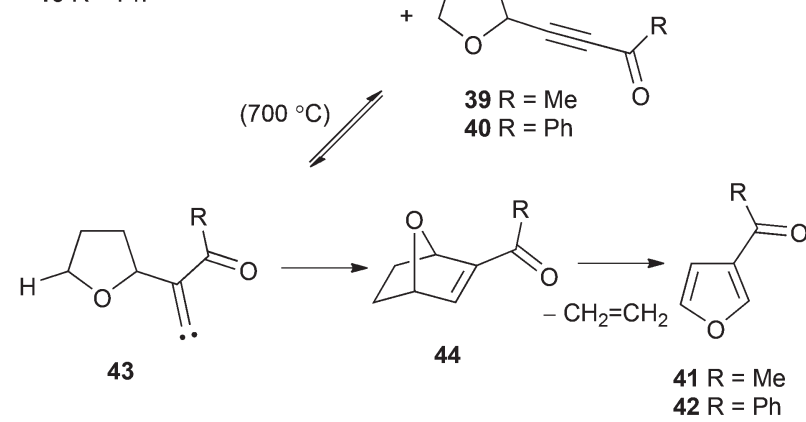

Scheme 9
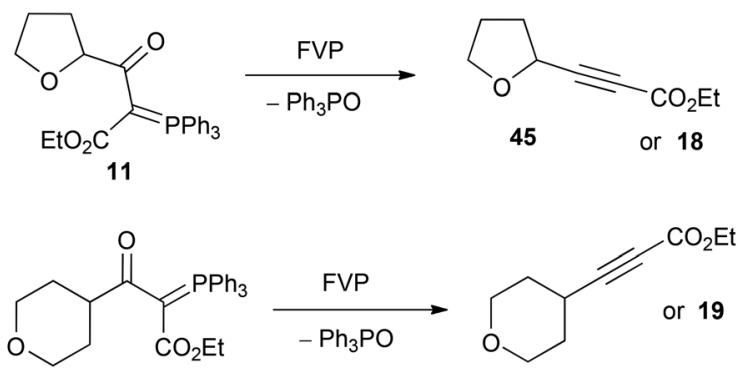

15

46

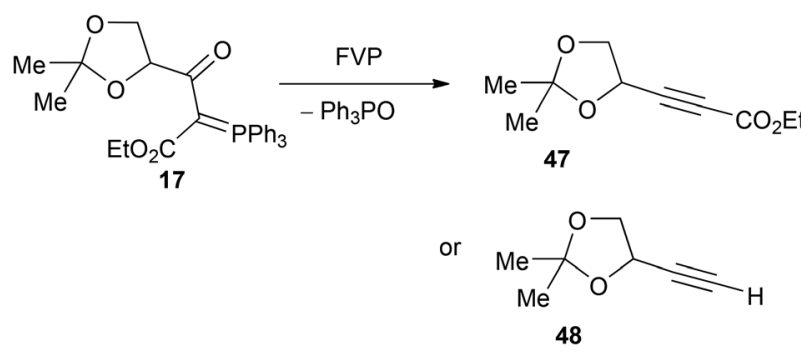

Scheme 10 insertion into the marked $\mathrm{CH}$ bond to give the oxabicyclic compounds $\mathbf{4 4}$ which are ideally set up to undergo retro-Diels Alder elimination of ethene to afford the observed acylfuran products.

Pyrolysis of ylides containing both adjacent ester and ketone carbonyl functions is well known to result in elimination of $\mathrm{Ph}_{3} \mathrm{PO}$ only from the latter to give acetylenic esters. The method was first developed by Märkl using conventional pyrolysis of methyl esters, ${ }^{3}$ but was later shown to also be amenable to FVP conditions using ethyl esters. ${ }^{38}$ An added advantage of using the latter technique is that, while efficient $\mathrm{Ph}_{3} \mathrm{PO}$ elimination to give the acetylenic esters occurs at $500{ }^{\circ} \mathrm{C}$, simply increasing the temperature to $750{ }^{\circ} \mathrm{C}$ additionally leads to loss of the whole ester group to afford the alk-1ynes. Mechanistic studies of this unusual process have been described. ${ }^{39}$ In agreement with this pattern, when the three ester-containing ylides 11, 15, and 17 were subjected to FVP, mixtures of the acetylenic esters and the alk-1-ynes were obtained with the ratio depending on the temperature (Scheme 10). Thus at $500{ }^{\circ} \mathrm{C}$, FVP of 11 gave ester $45(42 \%)$ together with the alkyne 18 (16\%). At $750{ }^{\circ} \mathrm{C}$, there was extensive decomposition with only products such as furan and cyclopentadiene isolated in low yield. FVP of the tetrahydropyan ylide 15 at $500{ }^{\circ} \mathrm{C}$ gave the ester 46 in $60 \%$ yield, while increasing the furnace temperature to $750{ }^{\circ} \mathrm{C}$ led to alkyne 19 $(30 \%)$ together with the decomposition products cyclopentadiene $(20 \%)$ and acetaldehyde (25\%) formed from 19 as shown in Scheme 4.

FVP of 17 at $600{ }^{\circ} \mathrm{C}$ gave mainly the ester 47 (68\%) with a little of the alkyne $48(9 \%)$ while at $650{ }^{\circ} \mathrm{C}$ the ratio of products had changed to $47(39 \%)$ and 48 (30\%). It therefore appears that lower temperature FVP of these three ylides provides an effective route to the acetylenic esters but for the alk-1-ynes FVP of ylides such as $\mathbf{6}$ and $\mathbf{1 2}$ is preferable.

\section{Experimental}

Instrumentation, general techniques and starting materials

Melting points were recorded on a Kofler hot-stage microscope and are uncorrected. Infra red spectra were recorded as Nujol mulls for solids and as thin films for liquids on a Perkin Elmer 1420 instrument. NMR spectra were obtained for ${ }^{1} \mathrm{H}$ at 300,400 or $500 \mathrm{MHz}$, for ${ }^{13} \mathrm{C}$ at 75,100 or $125 \mathrm{MHz}$ and for ${ }^{31} \mathrm{P}$ at $121 \mathrm{MHz}$ all using Bruker instruments. All spectra were run on solutions in $\mathrm{CDCl}_{3}$ with internal $\mathrm{Me}_{4} \mathrm{Si}$ as reference for ${ }^{1} \mathrm{H}$ and ${ }^{13} \mathrm{C}$ and external $\mathrm{H}_{3} \mathrm{PO}_{4}$ for ${ }^{31} \mathrm{P}$. Chemical shifts are reported in $\mathrm{ppm}$ to high frequency of the reference and coupling constants $J$ are in Hz. Mass spectra were obtained on a Micromass LCT spectrometer using electrospray ionisation.

Tetrahydrofuran-2-carbonyl chloride was prepared $(87 \%)$ by reaction of the commercially available acid with oxalyl chloride, tetrahydropyran-4-carbonyl chloride was prepared by hydrolysis of methyl tetrahydropyran-4-carboxylate using sodium hydroxide (quant.) followed by reaction with thionyl chloride (84\%), while 2,2-dimethyl-1,3-dioxolane-4-carbonyl chloride was prepared from mannitol diacetonide by sodium periodate cleavage $^{19}$ followed by potassium permanganate oxidation of the resulting aldehyde and treatment of the potassium carboxylate with oxalyl chloride. ${ }^{20}$

\section{General procedure A for synthesis of monostabilised ylides}

A suspension of the appropriate phosphonium salt (1 equiv.) in dry THF was stirred at rt under nitrogen while a solution of $n$-BuLi in hexanes (2.5 M, 1 equiv.) was added dropwise by syringe. After the addition the mixture was stirred for $30 \mathrm{~min}$ and then a solution of the acid chloride ( 0.5 equiv.) in dry THF was added dropwise. The mixture was stirred for $12 \mathrm{~h}$ and then 
partitioned between water and diethyl ether. The organic extract was dried $\left(\mathrm{MgSO}_{4}\right)$ and evaporated to give the product. If necessary a little EtOAc was added to induce crystallisation and the products were recrystallised from EtOAc.

\section{General procedure B for synthesis of distabilised ylides}

A solution of the appropriate stabilised ylide (1 equiv.) and triethylamine (1 equiv.) in dry toluene $\left(15 \mathrm{~cm}^{3}\right)$ was stirred at rt while a solution of the acid chloride (1 equiv.) in dry toluene $\left(5 \mathrm{~cm}^{3}\right)$ was added dropwise. After stirring for $12 \mathrm{~h}$, the mixture was filtered to remove triethylamine hydrochloride and the filtrate was evaporated to give the product. If necessary a little EtOAc was added to induce crystallisation and the products were recrystallised from EtOAc.

\section{Tetrahydrofuran-containing ylides}

1-(Tetrahydrofuran-2-yl)-2-(triphenylphosphoranylidene)ethan1-one 6. Reaction using procedure A with methyltriphenylphosphonium bromide (10.62 g, $29.7 \mathrm{mmol}$ ) in THF $\left(50 \mathrm{~cm}^{3}\right), 2.5 \mathrm{M} \mathrm{n}$-BuLi $\left(12.34 \mathrm{~cm}^{3}, 29.7 \mathrm{mmol}\right)$ and tetrahydrofuran-2-carbonyl chloride $(2.00 \mathrm{~g}, 14.86 \mathrm{mmol})$ in THF $\left(20 \mathrm{~cm}^{3}\right)$ gave the product $(1.97 \mathrm{~g}, 35 \%)$ as pale yellow crystals, mp 187-189 ${ }^{\circ} \mathrm{C}$ (from EtOAc) (Found 375.1504. $\mathrm{C}_{24} \mathrm{H}_{24} \mathrm{O}_{2} \mathrm{P}$ $(\mathrm{M}+\mathrm{H})$ requires 375.1514); $\nu_{\max } / \mathrm{cm}^{-1} 1531(\mathrm{CO}), 1102,1072$, $872,758,716$ and $696 ; \delta_{\mathrm{H}}(300 \mathrm{MHz}) 7.70-7.60(6 \mathrm{H}, \mathrm{m})$, 7.60-7.50 (3 H, m), 7.50-7.40 (6 H, m), 4.40-4.30 (1 H, m, 2-H), 4.16 ( $1 \mathrm{H}, \mathrm{d}, \mathrm{J} 26.3, \mathrm{CH}=\mathrm{P}), 4.10-4.00$ (1 H, m, 5-H), 3.90-3.80 $(1 \mathrm{H}, \mathrm{m}, 5-\mathrm{H}), 2.30-2.15(1 \mathrm{H}, \mathrm{m})$ and $2.10-1.80(3 \mathrm{H}, \mathrm{m}) ; \delta_{\mathrm{C}}$ $(100 \mathrm{MHz}) 193.6$ (d, J 3, CO), 133.0 (d, J 10, C-2 of Ph), 132.0 (d, $J$ 1, C-4 of Ph), 128.8 (d, J 12, C-3 of Ph), 127.0 (d, J 90, C-1 of $\mathrm{Ph}), 83.0$ (d, J 13, 2-CH), $68.9\left(5-\mathrm{CH}_{2}\right), 48.5(\mathrm{~d}, J 109, \mathrm{P}=\mathrm{CH})$, $30.9\left(3-\mathrm{CH}_{2}\right)$ and $25.7\left(4-\mathrm{CH}_{2}\right) ; \delta_{\mathrm{P}}(121 \mathrm{MHz})+16.2 ; \mathrm{m} / z$ (ESI) $771.28(2 \mathrm{M}+\mathrm{Na}, 7 \%), 397.13(\mathrm{M}+\mathrm{Na}, 12)$ and $375.15(\mathrm{M}+\mathrm{H}$, 100).

1-(Tetrahydrofuran-2-yl)-2-(triphenylphosphoranylidene)propan1-one 7. Reaction using procedure A with ethyltriphenylphosphonium bromide (5.6 g, $15 \mathrm{mmol})$ in THF $\left(40 \mathrm{~cm}^{3}\right), 2.5 \mathrm{M}$ $n$-BuLi $\left(6.0 \mathrm{~cm}^{3}, 15 \mathrm{mmol}\right)$ and tetrahydrofuran-2-carbonyl chloride $(1.0 \mathrm{~g}, 7.43 \mathrm{mmol})$ in THF $\left(10 \mathrm{~cm}^{3}\right)$ gave the product $(1.20 \mathrm{~g}, 41 \%)$ as colourless crystals, $\mathrm{mp}$ 115-117 $^{\circ} \mathrm{C}$ (from EtOAc) (Found 389.1620. $\quad \mathrm{C}_{25} \mathrm{H}_{26} \mathrm{O}_{2} \mathrm{P}(\mathrm{M}+\mathrm{H})$ requires 389.1670); $\nu_{\max } / \mathrm{cm}^{-1} 1520$ (CO), 1105, 923, 750, 711 and 693; $\delta_{\mathrm{H}}(300 \mathrm{MHz}) 7.60-7.39(15 \mathrm{H}, \mathrm{m}), 4.87(1 \mathrm{H}, \mathrm{td}, J$ 7.2, 1.2, 2-H), 4.04-3.97 (1 H, m, 5-H), 3.90-3.83 (1 H, m, 5-H), 2.15-2.07 (1 H, m), 2.00-1.60 (3 H, m) and 1.68 (3 H, d, J 16.5, Me); $\delta_{\mathrm{C}}(75 \mathrm{MHz}) 188.4(\mathrm{~d}, J 4, \mathrm{CO}), 133.4$ (d, $J 10, \mathrm{C}-2$ of $\left.\mathrm{Ph}\right), 131.3$ (d, J 3, C-4 of Ph), 128.5 (d, J 12, C-3 of Ph), 127.3 (d, J 90, C-1 of $\mathrm{Ph}$ ), 78.8 (d, J 14, 2-CH), $68.8\left(5-\mathrm{CH}_{2}\right), 55.7$ (d, $\left.J 107, \mathrm{P}=\mathrm{C}\right)$, $29.3\left(3-\mathrm{CH}_{2}\right), 25.9\left(4-\mathrm{CH}_{2}\right)$ and $12.3(\mathrm{~d}, J 12, \mathrm{Me}) ; \delta_{\mathrm{P}}(121 \mathrm{MHz})$ +17.9; $m / z$ (ESI) $389.16(\mathrm{M}+\mathrm{H}, 100)$.

2-Phenyl-1-(tetrahydrofuran-2-yl)-2-(triphenylphosphanylidene) ethan-1-one 8. Reaction using procedure A with benzyltriphenylphosphonium chloride $(5.78 \mathrm{~g}, 14.86 \mathrm{mmol})$ in THF $\left(20 \mathrm{~cm}^{3}\right), 2.5 \mathrm{M} n$-BuLi $\left(6.0 \mathrm{~cm}^{3}, 15.0 \mathrm{mmol}\right)$ and tetrahydrofuran-2-carbonyl chloride $(1.0 \mathrm{~g}, 7.43 \mathrm{mmol})$ in THF $\left(10 \mathrm{~cm}^{3}\right)$ gave the product $(0.78 \mathrm{~g}, 23 \%)$ as pale yellow crystals, $\mathrm{mp}$
179-182 ${ }^{\circ} \mathrm{C}$ (from EtOAc) (Found 451.1809. $\mathrm{C}_{30} \mathrm{H}_{28} \mathrm{O}_{2} \mathrm{P}(\mathrm{M}+\mathrm{H})$ requires 451.1827$) ; \nu_{\max } / \mathrm{cm}^{-1} 1530$ (CO), 1223, 1106, 1068, 746, 701 and 693; $\delta_{\mathrm{H}}(300 \mathrm{MHz}) 7.57-7.42(9 \mathrm{H}, \mathrm{m}), 7.38-7.32$ (6 H, m), 7.05-6.95 (5 H, m), 4.58 (1 H, t, J 6.4, 2-H), 4.00-3.92 (1 H, m, 5-H), 3.80-3.73 (1 H, m, 5-H), 1.99-1.82 (3 H, m) and 1.73-1.65 (1 H, m); $\delta_{\mathrm{C}}(125 \mathrm{MHz}) 189.0$ (d, J 5, CO), $137.2(\mathrm{~d}$, $J$ 11, C-1 of Ph), 135.0 (d, J 5, C-2 of Ph), 133.6 (d, $J$ 10, C-2 of PPh), 131.4 (d, J 3, C-4 of PPh), 128.4 (d, J 12, C-3 of PPh), 127.5 (d, $J$ 1, C-3 of Ph), 126.8 (d, J 90, C-1 of PPh), 125.2 (d, $J$ 3, C-4 of Ph), 78.2 (d, J 12, 2-CH), 70.2 (d, $J 106, \mathrm{P}=\mathrm{C}$ ), 69.2 $\left(5-\mathrm{CH}_{2}\right), 30.4\left(3-\mathrm{CH}_{2}\right)$ and $26.2\left(4-\mathrm{CH}_{2}\right) ; \delta_{\mathrm{P}}(121 \mathrm{MHz})+15.5 ; \mathrm{m} / \mathrm{z}$ (ESI) $923.34(2 \mathrm{M}+\mathrm{Na}, 42 \%), 473.16(\mathrm{M}+\mathrm{Na}, 6)$ and 451.18 $(\mathrm{M}+\mathrm{H}, 100)$.

1-(Tetrahydrofuran-2-yl)-2-(triphenylphosphoranylidene)butane1,3-dione 9. Reaction using procedure $\mathrm{B}$ with triphenylphosphoranylideneacetone $(2.37 \mathrm{~g}, 7.43 \mathrm{mmol})$, triethylamine $\left(1.03 \mathrm{~cm}^{3}, 0.75 \mathrm{~g}, 7.43 \mathrm{mmol}\right)$ and tetrahydrofuran-2-carbonyl chloride $(1.00 \mathrm{~g}, 7.43 \mathrm{mmol})$ in toluene $\left(20 \mathrm{~cm}^{3}\right)$ gave the product $(2.4 \mathrm{~g}, 77 \%)$ as colourless crystals, mp $127.5-129.5{ }^{\circ} \mathrm{C}$ (from EtOAc) (Found 439.1421. $\mathrm{C}_{26} \mathrm{H}_{25} \mathrm{NaO}_{3} \mathrm{P}(\mathrm{M}+\mathrm{Na})$ requires 439.1439); $\nu_{\max } / \mathrm{cm}^{-1} 1553(\mathrm{CO}), 1108,1066,757$ and 698; $\delta_{\mathrm{H}}$ (300 MHz) 7.70-7.60 (6 H, m), 7.50-7.35 (9 H, m), $4.86(1 \mathrm{H}$, $\mathrm{dd}, J$ 7.5, 5.4, 2-H), 3.89-3.82 (1 H, m, 5-H), 3.76-3.69 (1 H, m, 5-H), 2.15-2.00 (2 H, m), 2.09 (3 H, d, J 0.6, Me) and 1.82-1.72 (2 H, m); $\delta_{\mathrm{C}}(75 \mathrm{MHz}) 196.2$ (d, J 7, 1-CO), 192.7 (d, J 10, 3-CO), 133.0 (d, $J$ 10, C-2 of Ph), 131.6 (d, J 3, C-4 of Ph), 128.5 (d, J 12, C-3 of Ph), 126.3 (d, $J$ 91, C-1 of Ph), 86.0 (d, $J$ 100, P=C), 80.9 (d, $J$ 6, 2-CH), $68.8\left(5-\mathrm{CH}_{2}\right), 30.1$ (d, $\left.J 4, \mathrm{Me}\right), 29.6\left(3-\mathrm{CH}_{2}\right)$ and $25.3\left(4-\mathrm{CH}_{2}\right) ; \delta_{\mathrm{P}}(121 \mathrm{MHz})+15.6 ; \mathrm{m} / z(\mathrm{ESI}) 855.30(2 \mathrm{M}+\mathrm{Na}$, $12 \%), 439.14(\mathrm{M}+\mathrm{Na}, 100)$ and $417.16(\mathrm{M}+\mathrm{H}, 18)$.

1-Phenyl-3-(tetrahydrofuran-2-yl)-2-(triphenylphosphoranylidene)propane-1,3-dione 10. Reaction using procedure $B$ with triphenylphosphoranylideneacetophenone $(2.83 \mathrm{~g}$, $7.43 \mathrm{mmol})$, triethylamine $\left(1.03 \mathrm{~cm}^{3}, 0.75 \mathrm{~g}, 7.43 \mathrm{mmol}\right)$ and tetrahydrofuran-2-carbonyl chloride $(1.00 \mathrm{~g}, 7.43 \mathrm{mmol})$ in toluene $\left(20 \mathrm{~cm}^{3}\right)$ gave the product $(0.84 \mathrm{~g}, 24 \%)$ as pale yellow crystals, mp $179-181{ }^{\circ} \mathrm{C}$ (from EtOAc) (Found 479.1762. $\mathrm{C}_{31} \mathrm{H}_{28} \mathrm{O}_{3} \mathrm{P}(\mathrm{M}+\mathrm{H})$ requires 479.1776$) ; \nu_{\max } / \mathrm{cm}^{-1} 1546$ (CO), 1317, 1105, 1061, 713 and 694; $\delta_{\mathrm{H}}(300 \mathrm{MHz}) 7.70-7.60(8 \mathrm{H}$, m), 7.50-7.25 (12 H, m), 4.54 (1 H, t, J 6.7, 2-H), 3.85-3.70 (1 H, $\mathrm{m}, 5-\mathrm{H}), 3.65-3.55(1 \mathrm{H}, \mathrm{m}, 5-\mathrm{H}), 1.85-1.75(2 \mathrm{H}, \mathrm{m})$ and 1.70-1.57 (2 H, m); $\delta_{\mathrm{C}}(75 \mathrm{MHz}) 195.0$ (d, J 3, CO), 192.8 (d, $J$ 10, CO), 143.4 (d, $J$ 8, C-1 of COPh), 133.2 (d, $J$ 10, C-2 of PPh), 131.7 (d, J 3, C-4 of PPh), 130.8 (C-4 of COPh), 128.8 (2CH of COPh), 128.5 (d, J 12, C-3 of PPh), 128.1 (2CH of COPh), 125.7 (d, J 92, C-1 of PPh), 83.3 (d, J 100, P=C), 79.7 (d, $J$ 9, 2-CH), $69.1\left(5-\mathrm{CH}_{2}\right), 30.1\left(3-\mathrm{CH}_{2}\right)$ and $25.4\left(4-\mathrm{CH}_{2}\right)$; $\delta_{\mathrm{P}}(121 \mathrm{MHz})+17.5 ; \mathrm{m} / \mathrm{z}(\mathrm{ESI}) 979.33(2 \mathrm{M}+\mathrm{Na}, 62 \%), 501.16$ $(\mathrm{M}+\mathrm{Na}, 55)$ and $479.18(\mathrm{M}+\mathrm{H}, 100)$.

Ethyl 3-oxo-3-(tetrahydrofuran-2-yl)-2-(triphenylphosphoranylidene)propanoate 11. Reaction using procedure $B$ with ethyl triphenylphosphoranylideneacetate $(2.58 \mathrm{~g}, 7.43 \mathrm{mmol})$, triethylamine $\left(1.03 \mathrm{~cm}^{3}, 0.75 \mathrm{~g}, 7.43 \mathrm{mmol}\right)$ and tetrahydrofuran-2-carbonyl chloride $(1.00 \mathrm{~g}, 7.43 \mathrm{mmol})$ in toluene $\left(20 \mathrm{~cm}^{3}\right)$ gave the product $(0.82 \mathrm{~g}, 25 \%)$ as colourless crystals, mp 175-177 ${ }^{\circ} \mathrm{C}$ (from EtOAc) (Found 447.1712. $\mathrm{C}_{27} \mathrm{H}_{28} \mathrm{O}_{4} \mathrm{P}$ 
$(\mathrm{M}+\mathrm{H})$ requires 447.1725); $\nu_{\max } / \mathrm{cm}^{-1} 1654(\mathrm{CO}), 1575$ (CO), 1299, 1105, 1082, 750 and 692; $\delta_{\mathrm{H}}(300 \mathrm{MHz}) 7.70-7.60(6 \mathrm{H}$, m), 7.58-7.38 (9 H, m), 5.51 (1 H, ddd, $J$ 8.2, 5.2, 1.0, 2-H), 3.95-3.80 (2 H, m, 5-H), 3.80-3.65 (2 H, m, $\mathrm{CH}_{2}$ of $\left.\mathrm{Et}\right)$, 2.50-2.38 (1 H, m), 2.10-1.90 (1H, m), 1.90-1.75 (2 H, m) and 0.67 (3 H, t, J 7.1, $\mathrm{CH}_{3}$ of Et); $\delta_{\mathrm{C}}(100 \mathrm{MHz}) 196.6$ (d, J 3, 3-CO), 167.4 (d, J 15, 1-CO), 133.0 (d, J 10, C-2 of Ph), 131.5 (d, J 2, C-4 of Ph), 128.4 (d, J 12, C-3 of Ph), 126.5 (d, $J$ 93, C-1 of Ph), 80.7 (d, J 9, 2-CH), $69.1\left(5-\mathrm{CH}_{2}\right), 68.8$ (d, J 109, P=C), 58.4 (OEt), $30.9\left(3-\mathrm{CH}_{2}\right), 25.2\left(4-\mathrm{CH}_{2}\right)$ and $13.7(\mathrm{OEt}) ; \delta_{\mathrm{P}}(121 \mathrm{MHz})+17.1$; $m / z$ (ESI) $915.32(2 \mathrm{M}+\mathrm{Na}, 20 \%)$ and $447.17(\mathrm{M}+\mathrm{H}, 100)$.

\section{Tetrahydropyran-containing ylides}

1-(Tetrahydropyran-4-yl)-2-(triphenylphosphoranylidene) ethanone 12. Reaction using procedure A with methyltriphenylphosphonium bromide $(9.61 \mathrm{~g}, 26.9 \mathrm{mmol})$ in THF $\left(50 \mathrm{~cm}^{3}\right), 2.5 \mathrm{M} \mathrm{n}$-BuLi (11.17 $\left.\mathrm{cm}^{3}, 26.9 \mathrm{mmol}\right)$ and tetrahydropyran-4-carbonyl chloride $(2.00 \mathrm{~g}, 13.45 \mathrm{mmol})$ in THF $\left(20 \mathrm{~cm}^{3}\right)$ gave the product $(1.21 \mathrm{~g}, 23 \%)$ as pale orange crystals, mp 162-164 ${ }^{\circ} \mathrm{C}$ (from EtOAc) (Found 389.1659. $\mathrm{C}_{25} \mathrm{H}_{26} \mathrm{O}_{2} \mathrm{P}$ $(\mathrm{M}+\mathrm{H})$ requires 389.1670); $\nu_{\max } / \mathrm{cm}^{-1} 1540(\mathrm{CO}), 1400,1110$, 1082, 860, 752, and 697; $\delta_{\mathrm{H}}(300 \mathrm{MHz}) 7.70-7.60(6 \mathrm{H}, \mathrm{m})$, 7.60-7.50 (3 H, m), 7.50-7.40 (6 H, m), 4.10-3.95 (2 H, m), 3.70 (1 H, d, J 25.8, $\mathrm{CH}=\mathrm{P}), 3.50-3.35(2 \mathrm{H}, \mathrm{m}), 2.45-2.30(1 \mathrm{H}, \mathrm{m}$, 4-H) and 1.90-1.75 (4 H, m); $\delta_{\mathrm{C}}(100 \mathrm{MHz}) 195.1$ (d, J 1, CO), 132.9 (d, $J$ 10, C-2 of Ph), 131.9 (d, J 1, C-4 of Ph), 128.8 (d, $J 12$, C-3 of Ph), 127.2 (d, $J$ 90, C-1 of Ph), $68.1\left(2,6-\mathrm{CH}_{2}\right), 49.2$ (d, $J 107, \mathrm{P}=\mathrm{CH}), 46.2(\mathrm{~d}, J 14,4-\mathrm{CH})$ and $30.8\left(3,5-\mathrm{CH}_{2}\right) ; \delta_{\mathrm{P}}$ (121 MHz) +15.9; $m / z$ (ESI) 389.17 (M + H, 100).

1-(Tetrahydropyran-4-yl)-2-(triphenylphosphoranylidene) propan-1-one 13. Reaction using procedure A with ethyltriphenylphosphonium bromide $(5.00 \mathrm{~g}, 13.4 \mathrm{mmol})$ in THF $\left(40 \mathrm{~cm}^{3}\right), 2.5 \mathrm{M} \mathrm{n}$-BuLi $\left(5.40 \mathrm{~cm}^{3}, 13.4 \mathrm{mmol}\right)$ and tetrahydropyran-4-carbonyl chloride $(1.00 \mathrm{~g}, 6.73 \mathrm{mmol})$ in THF $\left(10 \mathrm{~cm}^{3}\right)$ gave the product $(0.71 \mathrm{~g}, 26 \%)$ as yellow crystals, $\mathrm{mp}$ 183-185 ${ }^{\circ} \mathrm{C}$ (from EtOAc) (Found 403.1810. $\mathrm{C}_{26} \mathrm{H}_{28} \mathrm{O}_{2} \mathrm{P}(\mathrm{M}+\mathrm{H})$ requires 403.1827$) ; \nu_{\max } / \mathrm{cm}^{-1} 1520$ (CO), 1099, 856, 754, 716 and 697; $\delta_{\mathrm{H}}(300 \mathrm{MHz}) 7.60-7.35(15 \mathrm{H}, \mathrm{m}), 4.10-3.95(2 \mathrm{H}, \mathrm{m})$, 3.50 ( $2 \mathrm{H}, \mathrm{td}, J 12,3), 2.93$ (1 H, tt, $J$ 7.8, 3.9, 4-H), 1.95-1.80 (2 $\mathrm{H}, \mathrm{m}), 1.66$ (3 H, d, J 16.2, Me) and 1.66-1.55 (2 H, m); $\delta_{\mathrm{C}}$ (75 MHz) 191.2 (d, J 4, CO), 133.3 (d, J 10, C-2 of Ph), 131.2 (d, $J$ 3, C-4 of Ph), 128.4 (d, $J$ 12, C-3 of Ph), 128.0 (d, $J$ 90, C-1 of $\mathrm{Ph}), 68.1$ (2,6- $\left.\mathrm{CH}_{2}\right), 55.4$ (d, $\left.J 106, \mathrm{P}=\mathrm{C}\right), 40.7$ (d, $J$ 10, 4-CH), $29.2\left(3,5-\mathrm{CH}_{2}\right)$ and $12.7(\mathrm{~d}, J 14, \mathrm{Me}) ; \delta_{\mathrm{P}}(121 \mathrm{MHz})+16.8 ; \mathrm{m} / \mathrm{z}$ (ESI) $425.16(\mathrm{M}+\mathrm{Na}, 12 \%)$ and $403.18(\mathrm{M}+\mathrm{H}, 100)$.

2-Phenyl-1-(tetrahydropyran-4-yl)-2-(triphenylphosphoranylidene)ethan-1-one 14. Reaction using procedure A with benzyltriphenylphosphonium chloride $(5.23 \mathrm{~g}, 13.4 \mathrm{mmol})$ in THF $\left(20 \mathrm{~cm}^{3}\right), 2.5 \mathrm{M} \mathrm{n}$-BuLi $\left(5.4 \mathrm{~cm}^{3}, 13.46 \mathrm{mmol}\right)$ and tetrahydropyran-4-carbonyl chloride $(1.00 \mathrm{~g}, 6.73 \mathrm{mmol})$ in THF $\left(10 \mathrm{~cm}^{3}\right)$ gave the product $(0.20 \mathrm{~g}, 6 \%)$ as pale yellow crystals, $\mathrm{mp}$ $178-182{ }^{\circ} \mathrm{C}$ (from EtOAc) (Found 465.1962. $\mathrm{C}_{31} \mathrm{H}_{30} \mathrm{O}_{2} \mathrm{P}(\mathrm{M}+\mathrm{H}$ ) requires 465.1983); $\nu_{\max } / \mathrm{cm}^{-1} 1520$ (CO), 1124, 1105, 861, 756, 709 and $691 ; \delta_{\mathrm{H}}(300 \mathrm{MHz}) 7.60-7.40(9 \mathrm{H}, \mathrm{m}), 7.40-7.30(6 \mathrm{H}$, m), 7.05-6.95 (5 H, m), 3.95-3.85 (2 H, m), 3.24 (2 H, td, J 12, 2), $2.74(1 \mathrm{H}, \mathrm{tt}, J 11.4,3.9,4-\mathrm{H}), 1.95-1.75(2 \mathrm{H}, \mathrm{m})$ and
1.55-1.48 (2 H, m); $\delta_{\mathrm{C}}(125 \mathrm{MHz}) 191.4$ (d, J 5, CO), 137.9 (d, $J$ 13, C-1 of Ph), 134.8 (d, J 5, C-2 of Ph), 133.5 (d, J 10, C-2 of PPh), 131.2 (d, J 3, C-4 of PPh), 128.3 (d, $J$ 12, C-3 of PPh), 127.6 (d, $J$ 2, C-3 of Ph), 127.4 (d, J 90, C-1 of PPh), 125.1 (d, $J$ 2, C-4 of Ph), 70.1 (d, $J 108, \mathrm{P}=\mathrm{C}$ ), $67.8\left(2,6-\mathrm{CH}_{2}\right), 41.1$ (d, $J$ 9, 4-CH) and $29.6\left(3,5-\mathrm{CH}_{2}\right) ; \delta_{\mathrm{P}}(121 \mathrm{MHz})+14.9 ; \mathrm{m} / z$ (ESI) 951.37 $(2 \mathrm{M}+\mathrm{Na}, 18 \%), 487.18(\mathrm{M}+\mathrm{Na}, 27 \%)$ and $465.20(\mathrm{M}+\mathrm{H}$, 100).

Ethyl 3-oxo-3-(tetrahydropyran-4-yl)-2-(triphenylphosphoranylidene)propanoate 15. Reaction using procedure $B$ with ethyl triphenylphosphoranylideneacetate $(2.34 \mathrm{~g}, 6.73 \mathrm{mmol})$, triethylamine $\left(0.94 \mathrm{~cm}^{3}, 0.68 \mathrm{~g}, 6.73 \mathrm{mmol}\right)$ and tetrahydropyran-4-carbonyl chloride $(0.89 \mathrm{~g}, 6.73 \mathrm{mmol})$ in toluene $\left(20 \mathrm{~cm}^{3}\right)$ gave the product $(2.05 \mathrm{~g}, 66 \%)$ as pale yellow crystals, mp 170-171 ${ }^{\circ} \mathrm{C}$ (from EtOAc) (Found 461.1867. $\mathrm{C}_{28} \mathrm{H}_{30} \mathrm{O}_{4} \mathrm{P}$ $(\mathrm{M}+\mathrm{H})$ requires 461.1882); $\nu_{\max } / \mathrm{cm}^{-1} 1657$ (CO), 1556 (CO), 1291, 1107, 1080, 1063, 746 and 693; $\delta_{\mathrm{H}}(300 \mathrm{MHz}) 7.65-7.55$ (6 H, m), 7.55-7.35 (9 H, m), 4.01-3.93 (2 H, m), $3.81(1 \mathrm{H}, \mathrm{tt}$, $J$ 11.4, 3.9, 4-H), 3.70 (2 H, q, J 7.1, OEt), 3.54 (2 H, td, $J$ 11.3, 3.0), 1.85-1.60 (4 H, m, 3,5-H) and 0.63 (3 H, t, $J$ 7.1, OEt); $\delta_{\mathrm{C}}$ (100 MHz) 198.9 (d, J 5, 3-CO), 167.5 (d, J 15, 1-CO), 132.9 (d, $J$ 10, C-2 of Ph), 131.5 (d, $J$ 3, C-4 of Ph), 128.4 (d, $J 12, \mathrm{C}-3$ of Ph), 126.9 (d, J 93, C-1 of Ph), 69.8 (d, J 109, P=C), 68.0 (2,6$\mathrm{CH}_{2}$ ), 58.3 (OEt), 43.3 (d, $J$ 7, 4-CH), $29.4\left(3,5-\mathrm{CH}_{2}\right)$ and 13.7 $(\mathrm{OEt}) ; \delta_{\mathrm{P}}(121 \mathrm{MHz})+17.5 ; \mathrm{m} / z$ (ESI) $943.35(2 \mathrm{M}+\mathrm{Na}, 32 \%)$, $483.17(\mathrm{M}+\mathrm{Na}, 7 \%)$ and $461.19(\mathrm{M}+\mathrm{H}, 100)$.

\section{1,3-Dioxolane-containing ylides}

1-(2,2-Dimethyl-1,3-dioxolan4-yl)-2-phenyl-2-(triphenylphosphoranylidene)ethan-1-one 16. Reaction using procedure $\mathrm{A}$ with benzyltriphenylphosphonium chloride (3.31 g, $8.5 \mathrm{mmol})$ in THF $\left(40 \mathrm{~cm}^{3}\right), 2.5 \mathrm{M} \mathrm{n}$-BuLi $\left(3.4 \mathrm{~cm}^{3}, 8.5 \mathrm{mmol}\right)$ and 2,2dimethyl-1,3-dioxolane-4-carbonyl chloride (0.70 g, $4.25 \mathrm{mmol}$ ) in THF $\left(10 \mathrm{~cm}^{3}\right)$ gave the product $(0.51 \mathrm{~g}, 25 \%)$ as colourless crystals, mp 169-171 ${ }^{\circ} \mathrm{C}$ (from EtOAc) (Found 481.1914. $\mathrm{C}_{31} \mathrm{H}_{30} \mathrm{O}_{3} \mathrm{P}(\mathrm{M}+\mathrm{H})$ requires 481.1933$) ; \nu_{\max } / \mathrm{cm}^{-1} 1717,1549$ (CO), 1523, 1103, 870, 761 and 694; $\delta_{\mathrm{H}}(300 \mathrm{MHz}) 7.60-7.40$ (9 H, m), 7.40-7.30 (6 H, m), 7.00-6.95 (5 H, m), 4.75 (1 H, ddd, $J$ 8.4, 6.9, 1.2), 3.895 ( $1 \mathrm{H}$, half AB pattern of $\mathrm{d}, J 7.5,6.9$ ), $3.86(1 \mathrm{H}$, half $\mathrm{AB}$ pattern of $\mathrm{d}, J 8.4,7.5), 1.41(3 \mathrm{H}, \mathrm{s}, \mathrm{Me})$ and $1.31(3 \mathrm{H}, \mathrm{s}, \mathrm{Me}) ; \delta_{\mathrm{C}}(75 \mathrm{MHz}) 184.3$ (d, J 6, CO), 136.5 (d, J 11, C-1 of Ph), 135.0 (d, $J$ 5, C-2 of Ph), 133.6 (d, J 10, C-2 of PPh), 131.5 (d, J 3, C-4 of PPh), 128.4 (d, J 12, C-3 of PPh), 127.7 (d, $J$ 2, C-3 of Ph), 126.3 (d, $J$ 91, C-1 of PPh), 125.6 (d, J 3, C-4 of $\mathrm{Ph}$ ), 109.7 (dioxolane C-2), 76.4 (d, $J$ 13, dioxolane C-4), 71.0 (d, $J$ 107, $\mathrm{P}=\mathrm{C}$ ), 68.0 (dioxolane $\mathrm{C}-5$ ), $26.2(\mathrm{Me})$ and $26.0(\mathrm{Me})$; $\delta_{\mathrm{P}}(121 \mathrm{MHz})+16.1 ; \mathrm{m} / \mathrm{z}(\mathrm{ESI}) 481.19(\mathrm{M}+\mathrm{H}, 100)$.

Ethyl 3-(2,2-dimethyl-1,3-dioxolan-4-yl)-3-oxo-2-(triphenylphosphoranylidene)propanoate 17 . Reaction using procedure B with ethyl triphenylphosphoranylideneacetate $(1.47 \mathrm{~g}$, $4.25 \mathrm{mmol})$, triethylamine $\left(0.60 \mathrm{~cm}^{3}, 0.43 \mathrm{~g}, 4.25 \mathrm{mmol}\right)$ and 2,2-dimethyl-1,3-dioxolan-4-carbonyl chloride $(0.70 \mathrm{~g}$, $4.25 \mathrm{mmol})$ in toluene $\left(10 \mathrm{~cm}^{3}\right)$ gave the product $(0.52 \mathrm{~g}, 26 \%)$ as colourless crystals, mp 154-156 ${ }^{\circ} \mathrm{C}$ (Found 477.1819. $\mathrm{C}_{28} \mathrm{H}_{30} \mathrm{O}_{5} \mathrm{P}(\mathrm{M}+\mathrm{H})$ requires 477.1831); $\nu_{\max } / \mathrm{cm}^{-1} 1655,1597$ (CO), 1300, 1288, 1104, 1088, 842, 756 and 689; $\delta_{\mathrm{H}}(500 \mathrm{MHz})$ 
7.70-7.60 (6 H, m), 7.60-7.50 (3 H, m), 7.50-7.40 (6 H, m), 5.51 (1 H, ddd, $J$ 7.5, 5.4, 1.2), 4.57 (1 H, dd, $J$ 8.2, 7.5), $4.16(1 \mathrm{H}$, $\mathrm{dd}, J$ 8.2, 5.4), 3.74 and 3.66 ( $2 \mathrm{H}, \mathrm{AB}$ pattern of $\mathrm{q}, J 10.5,7.2)$, 1.39 (3 H, s, Me), 1.36 (3 H, s, Me) and 0.64 (3 H, t, J 7.2, OEt); $\delta_{\mathrm{C}}(125 \mathrm{MHz}) 193.2$ (d, $J$ 3, 3-CO), 167.5 (d, $J$ 14, 1-CO), 133.1 (d, J 10, C-2 of Ph), 131.6 (d, J 3, C-4 of Ph), 128.5 (d, J 12, C-3 of Ph), 126.1 (d, J 94, C-1 of Ph), 109.9 (dioxolane C-2), 79.1 (d, $J$ 9, dioxolane $\mathrm{C}-4), 68.94(\mathrm{~d}, J$ 110, $\mathrm{P}=\mathrm{C}$ ), 68.89 (dioxolane C-5), 58.4 (OEt), 26.1 (Me), 25.7 (Me) and 13.6 (OEt); $\delta_{\mathrm{P}}$ (121 MHz) +16.9; m/z (ESI) 975.34 (2M + Na, 35\%), 499.16 $(\mathrm{M}+\mathrm{Na}, 60), 477.18(\mathrm{M}+\mathrm{H}, 100)$.

\section{$\mathrm{X}$-ray structure determination}

Compound 10, $\mathrm{C}_{31} \mathrm{H}_{27} \mathrm{O}_{3} \mathrm{P}, M$ 478.53, yellow prism. Monoclinic, space group $P 2_{1} / c, a$ 9.9232(13), $b$ 21.836(2), $c$ 11.4086(13) $\AA$, $\beta$ 96.272(4) ${ }^{\circ}, V 2457.3(5) \AA^{3}, Z 4, D_{\mathrm{c}} 1.293 \mathrm{Mg} \mathrm{m}^{-3}, T 173 \mathrm{~K}$, 26295 reflections, 4506 unique $\left(R_{\text {int }} 0.048\right) . R_{1} 0.0484, \mathrm{w} R_{2}$ $0.1407, R$ indices based on 3994 data with $I>2 \sigma(I), 316$ parameters. Data were recorded using a Rigaku XtaLB P200, Mo K $\alpha$ radiation (confocal optic, $\lambda 0.71073 \AA$ ) and Saturn detector. The structure was solved by direct methods and refined using full-matrix least-squares methods.

Compound 13, $\mathrm{C}_{26} \mathrm{H}_{27} \mathrm{O}_{2} \mathrm{P}, M$ 402.47, colourless prism. Monoclinic, space group $P 2_{1} / c, a$ 11.829(3), $b$ 11.011(3),

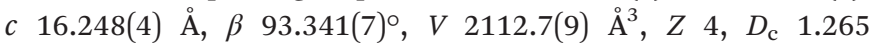
$\mathrm{Mg} \mathrm{m}^{-3}, T 93 \mathrm{~K}, 23466$ reflections, 3850 unique ( $R_{\text {int }}$ 0.0592). $R_{1} 0.0369, \mathrm{w} R_{2} 0.1090, R$ indices based on 3336 data with $I>$ $2 \sigma(I), 263$ parameters. Data were recorded using a Rigaku XtaLB P200, Mo K $\alpha$ radiation (confocal optic, $\lambda 0.71073 \AA$ ) and Saturn detector. The structure was solved by direct methods and refined using full-matrix least-squares methods.

Compound 17, $\mathrm{C}_{28} \mathrm{H}_{29} \mathrm{O}_{5} \mathrm{P}, M$ 476.51, colourless prism. Triclinic, space group $P 1, a$ 9.345(4), $b$ 10.512(3), $c$ 14.341(4) §, $\alpha$ 98.497(2), $\beta$ 106.816(11), $\gamma 110.513(8)^{\circ}, V 1213.3(7) \AA^{3}, Z 2, D_{\mathrm{c}}$ $1.304 \mathrm{Mg} \mathrm{m}^{-3}, T 125 \mathrm{~K}, 13591$ reflections, 6259 unique $\left(R_{\text {int }}\right.$ 0.0836). $R_{1} 0.0570, \mathrm{w} R_{2} \quad 0.1352, R$ indices based on 5802 data with $I>2 \sigma(I), 619$ parameters. Data were recorded using a Rigaku XtaLB P200, $\mathrm{Cu} \mathrm{K} \alpha$ radiation (confocal optic, $\lambda$ $1.54187 \AA$ A) and Saturn detector. The structure was solved by direct methods and refined using full-matrix least-squares methods.

Crystallographic data (excluding structure factors) for the structures included in this paper have been deposited at the Cambridge Crystallographic Data Centre as supplementary publication No. CCDC 1435297 (10), 1435298 (13) and 1435299 (17).

\section{Flash vacuum pyrolysis (FVP)}

This was carried out using the apparatus previously described. ${ }^{22}$ The contact time in the hot zone was estimated to be $\sim 10 \mathrm{~ms}$. In each case a solid collected at the furnace exit which was found to be either $\mathrm{Ph}_{3} \mathrm{PO}$ or a mixture of $\mathrm{Ph}_{3} \mathrm{PO}$ and $\mathrm{Ph}_{3} \mathrm{P}$. In the cold trap the other product(s) collected as a liquid or oil and this was dissolved out using either $\mathrm{CDCl}_{3}$ (small scale) for direct NMR analysis, or $\mathrm{CH}_{2} \mathrm{Cl}_{2}$ (large scale) for purification and characterisation by the usual methods.
FVP of ylide $6(150 \mathrm{mg})$ at $750{ }^{\circ} \mathrm{C}$ gave at the furnace exit $\mathrm{Ph}_{3} \mathrm{PO} ; \delta_{\mathrm{P}}+29.2$, and in the cold trap:

2-Ethynyltetrahydrofuran $18(14 \mathrm{mg}, 36 \%)$ as a colourless liquid (Found 95.0493. $\mathrm{C}_{6} \mathrm{H}_{7} \mathrm{O}(\mathrm{M}-\mathrm{H})$ requires 95.0497); $\delta_{\mathrm{H}}$ (300 MHz) 4.62-4.58 (1 H, m, 2-H), 4.00-3.92 (1 H, m, 5-H), 3.86-3.75 (1 H, m, 5-H), $2.43(1 \mathrm{H}, \mathrm{d}, J 2.0, \equiv \mathrm{CH})$ and 2.24-1.85 (m, 4H, 3,4-H); $\delta_{\mathrm{C}}(75 \mathrm{MHz}) 83.8(\mathrm{C},-\mathrm{C} \equiv), 72.5(\mathrm{CH}$, $-\mathrm{C} \equiv), 67.9\left(\mathrm{CH}_{2}, \mathrm{C}-5\right), 67.8(\mathrm{CH}, \mathrm{C}-2), 33.2\left(\mathrm{CH}_{2}\right)$ and 25.3 $\left(\mathrm{CH}_{2}\right)$.

FVP of ylide $12(110 \mathrm{mg})$ at $750{ }^{\circ} \mathrm{C}$ gave at the furnace exit $\mathrm{Ph}_{3} \mathrm{PO} ; \delta_{\mathrm{P}}+29.2$, and in the cold trap:

A mixture containing 4-ethynyltetrahydropyran $19(13 \mathrm{mg}$, $42 \%$ ) as a colourless liquid (Found: 111.0812. $\mathrm{C}_{7} \mathrm{H}_{11} \mathrm{O}(\mathrm{M}+\mathrm{H})$ requires 111.0810$) ; \nu_{\max } / \mathrm{cm}^{-1} 3293(\equiv \mathrm{C}-\mathrm{H}), 2240(\mathrm{C} \equiv \mathrm{C})$, 1262, 1090, 1058 and 813; $\delta_{\mathrm{H}}(400 \mathrm{MHz}) 3.905$ (2 H, ddd, $J$ 11.6, 5.6, 3.6, 2,6-H), 3.505 (2 H, ddd, $J$ 11.6, 8.4, 3.2, 2,6-H), 2.68-2.61 (1 H, m, 4-H), 2.11 (1 H, d, J 2.4, 三CH), 1.88-1.80 $(2 \mathrm{H}, \mathrm{m}, 3,5-\mathrm{H})$ and $1.74-1.64(2 \mathrm{H}, \mathrm{m}, 3,5-\mathrm{H}) ; \delta_{\mathrm{C}}(100 \mathrm{MHz})$ $86.6(\mathrm{C},-\mathrm{C} \equiv), 69.1(\mathrm{CH},-\mathrm{C} \equiv), 66.2\left(\mathrm{CH}_{2}\right), 32.0\left(\mathrm{CH}_{2}\right)$ and 25.9 $(\mathrm{CH})$, together with cyclopentadiene $(4 \%) ; \delta_{\mathrm{H}} 6.57(2 \mathrm{H}, \mathrm{m})$, $6.47(2 \mathrm{H}, \mathrm{m})$ and $2.99(2 \mathrm{H}, \mathrm{m}) ; \delta_{\mathrm{C}} 133.1(\mathrm{CH}), 132.2(\mathrm{CH})$ and $41.6\left(\mathrm{CH}_{2}\right)$ and acetaldehyde $(3 \%) ; \delta_{\mathrm{H}} 9.79(1 \mathrm{H}, \mathrm{q}, J 3)$ and 2.21 (3 H, d, J 3).

FVP of ylide $7(200 \mathrm{mg})$ at $730{ }^{\circ} \mathrm{C}$ gave at the furnace exit a $2: 1$ mixture of $\mathrm{Ph}_{3} \mathrm{P} ; \delta_{\mathrm{P}}-5.5$ and $\mathrm{Ph}_{3} \mathrm{PO} ; \delta_{\mathrm{P}}+29.2$, and in the cold trap:

A colourless liquid consisting of a mixture of 2-(prop-1ynyl)tetrahydrofuran $22(20 \%) ; \delta_{\mathrm{H}}(400 \mathrm{MHz}) 4.58-4.50(1 \mathrm{H}$, m, 2-H), 3.98-3.85 (2 H, m, 5-H), 1.90-1.80 (2 H, m), 1.75-1.70 $(2 \mathrm{H}, \mathrm{m})$ and 1.84 (3 H, d, $J 1.8) ; \delta_{\mathrm{C}}(100 \mathrm{MHz}) 79.0(\mathrm{C},-\mathrm{C} \equiv)$, $70.7(\mathrm{C},-\mathrm{C} \equiv), 68.3(\mathrm{CH}), 67.8\left(\mathrm{CH}_{2}\right), 33.3\left(\mathrm{CH}_{2}\right), 25.3\left(\mathrm{CH}_{2}\right)$ and $3.5(\mathrm{Me})$ [good agreement of $\delta_{\mathrm{H}}$ with lit. ${ }^{40}$ ] and 2-(propionyl)-4,5-dihydrofuran $24(30 \%)$ (Found 127.0754. $\quad \mathrm{C}_{7} \mathrm{H}_{11} \mathrm{O}_{2}$ $(\mathrm{M}+\mathrm{H})$ requires 127.0759); $\delta_{\mathrm{H}}(300 \mathrm{MHz}) 5.94(1 \mathrm{H}, \mathrm{t}, J 3.0)$, 4.47 (2 H, t, J 9.8), $2.82(2 \mathrm{H}, \mathrm{td}, 9.8,3.0), 2.65$ (2 H, q, J 7.2) and $1.12\left(3 \mathrm{H}, \mathrm{t}, J\right.$ 7.2); $\delta_{\mathrm{C}}(100 \mathrm{MHz}) 193.0(\mathrm{CO}), 156.0(=\mathrm{C}-)$, $110.7(=\mathrm{CH}-), 70.1\left(\mathrm{OCH}_{2}\right), 32.0\left(\mathrm{COCH}_{2}\right), 30.5\left(4-\mathrm{CH}_{2}\right)$ and $8.0\left(\mathrm{CH}_{3}\right)$. Preparative TLC allowed separation of the latter in pure form.

FVP of ylide $13(70 \mathrm{mg})$ at $710^{\circ} \mathrm{C}$ gave at the furnace exit $\mathrm{Ph}_{3} \mathrm{PO} ; \delta_{\mathrm{P}}+29.2$, and in the cold trap:

4-(Prop-1-ynyl)tetrahydropyran 25 (65\%) (Found: 125.0969. $\mathrm{C}_{8} \mathrm{H}_{13} \mathrm{O}(\mathrm{M}+\mathrm{H})$ requires 125.0966$) ; \nu_{\max } / \mathrm{cm}^{-1} 2233(\mathrm{C} \equiv \mathrm{C})$; $\delta_{\mathrm{H}}(300 \mathrm{MHz}) 3.89(2 \mathrm{H}$, ddd, $J 11.7,5.1,3.9,2,6-\mathrm{H}), 3.47(2 \mathrm{H}$, ddd, $J 11.7,8.7,2.8,2,6-\mathrm{H}), 2.60-2.50(1 \mathrm{H}, \mathrm{m}, 4-\mathrm{H}), 1.81(3 \mathrm{H}$, $\mathrm{d}, J$ 2.0) 1.82-1.74 (2 H, m, 3,5-H) and 1.68-1.55 (2 H, m, 3,5$\mathrm{H}) ; \delta_{\mathrm{C}}(75 \mathrm{MHz}) 81.7(\mathrm{C},-\mathrm{C} \equiv), 76.4(\mathrm{C},-\mathrm{C} \equiv), 66.5\left(\mathrm{CH}_{2}\right), 32.6$ $\left(\mathrm{CH}_{2}\right), 26.3(\mathrm{CH})$ and $3.5(\mathrm{Me})$.

FVP of ylide $8(80 \mathrm{mg})$ at $700{ }^{\circ} \mathrm{C}$ gave at the furnace exit $\mathrm{Ph}_{3} \mathrm{PO} ; \delta_{\mathrm{P}}+29.2$, and in the cold trap:

2-(Phenylethynyl)tetrahydrofuran 26 (56\%) as a colourless liquid (Found 195.0776. $\mathrm{C}_{12} \mathrm{H}_{12} \mathrm{ONa}(\mathrm{M}+\mathrm{Na})$ requires 195.0786); $\nu_{\max } / \mathrm{cm}^{-1} 2231(\mathrm{C} \equiv \mathrm{C}), 1727,1599,1490,1054,757$ and 692; $\delta_{\mathrm{H}}(300 \mathrm{MHz}) 7.6-7.2(5 \mathrm{H}, \mathrm{m}), 4.81(1 \mathrm{H}, \mathrm{dd}, J$ 7.2, 5.0, 2-H), 4.05-3.98 (1 H, m, 5-H), 3.89-3.82 (1 H, m, 5-H), 2.25-2.15 (1 H, m), 2.15-2.00 (2 H, m) and 2.00-1.85 (1 H, m); 
$\delta_{\mathrm{C}}(75 \mathrm{MHz}) 131.7(2 \mathrm{CH}), 128.22(\mathrm{CH}), 128.17(2 \mathrm{CH}), 122.8$ (C), $89.0(\mathrm{C},-\mathrm{C} \equiv), 84.4(\mathrm{C},-\mathrm{C} \equiv), 68.6\left(\mathrm{CH}_{2}\right), 67.9(\mathrm{CH}), 33.4$ $\left(\mathrm{CH}_{2}\right)$ and $25.5\left(\mathrm{CH}_{2}\right)$ [good agreement of $\delta_{\mathrm{H}}{ }^{27}$ and $\delta_{\mathrm{C}}{ }^{28}$ with lit.].

FVP of ylide $14(70 \mathrm{mg})$ at $700{ }^{\circ} \mathrm{C}$ gave at the furnace exit $\mathrm{Ph}_{3} \mathrm{PO} ; \delta_{\mathrm{P}}+29.2$, and in the cold trap:

A mixture of 4-(phenylethynyl)tetrahydropyran 27 (46\%) (Found 186.1042. $\quad \mathrm{C}_{13} \mathrm{H}_{14} \mathrm{O} \quad(\mathrm{M})$ requires 186.1045$) ; \quad \delta_{\mathrm{H}}$ (300 MHz) 7.45-7.25 (5 H, m), 4.00-3.89 (2 H, m, 2,6-H), 3.60-3.50 (2 H, m, 2,6-H), 2.90-2.80 (1 H, m, 4-H), 1.95-1.85 $(2 \mathrm{H}, \mathrm{m}, 3,5-\mathrm{H})$ and $1.82-1.70(2 \mathrm{H}, \mathrm{m}, 3,5-\mathrm{H}) ; \delta_{\mathrm{C}}(75 \mathrm{MHz})$ 131.6 (2 CH), 128.2 (2 CH), $126.6(\mathrm{CH}), 123.6(\mathrm{C}), 92.2$ $(\mathrm{C},-\mathrm{C} \equiv), 81.5(\mathrm{C},-\mathrm{C} \equiv), 66.4\left(\mathrm{CH}_{2}\right), 32.3\left(\mathrm{CH}_{2}\right)$ and $26.8(\mathrm{CH})$, and 4-(phenylvinylidene)tetrahydropyran $28 \quad(20 \%) ; \quad \delta_{\mathrm{H}}$ (300 MHz) 7.45-7.25 (5 H, m), 6.10 (1 H, quintet, $J$ 2.1), 3.89-3.75 (2 H, m, 2,6-H), 2.38-2.33 (2 H, m, 3,5-H); $\delta_{\mathrm{C}}$ $(75 \mathrm{MHz}) 200.7(=\mathrm{C}=), 135.2(\mathrm{C}), 128.6(2 \mathrm{CH}), 127.7(2 \mathrm{CH})$, $126.7(\mathrm{CH}), 101.9(=\mathrm{C}<), 93.7(=\mathrm{CH}), 68.8\left(\mathrm{CH}_{2}\right)$ and 31.3 $\left(\mathrm{CH}_{2}\right)$.

FVP of ylide $16(65 \mathrm{mg})$ at $650{ }^{\circ} \mathrm{C}$ gave at the furnace exit an $8: 1$ mixture of $\mathrm{Ph}_{3} \mathrm{PO} ; \delta_{\mathrm{P}}+29.2$ and $\mathrm{Ph}_{3} \mathrm{P} ; \delta_{\mathrm{P}}-5.5$, and in the cold trap:

4-Phenylethynyl-2,2-dimethyl-1,3-dioxolane $29 \quad(48 \%)$ (Found 225.0883. $\mathrm{C}_{13} \mathrm{H}_{14} \mathrm{O}_{2} \mathrm{Na}(\mathrm{M}+\mathrm{Na})$ requires 225.0891); $\nu_{\max } / \mathrm{cm}^{-1} 2234,2212(\mathrm{C} \equiv \mathrm{C}), 1709,1680,1599,1491,1065$, 758 and $692 ; \delta_{\mathrm{H}}(300 \mathrm{MHz}) 7.48-7.40(2 \mathrm{H}, \mathrm{m}), 7.35-7.25(3 \mathrm{H}$, m), 4.95 (1 H, t, J 6.3, 4-H), 4.24 (1 H, dd, J 8.0, 6.3, 5-H), 4.01 $(1 \mathrm{H}, \mathrm{dd}, J$ 8.0, 6.3, 5-H), $1.54(3 \mathrm{H}, \mathrm{q}, J 0.6)$ and $1.43(3 \mathrm{H}, \mathrm{q}$, $J$ 0.6); $\delta_{\mathrm{C}}(75 \mathrm{MHz}) 131.7(2 \mathrm{C}), 128.6(\mathrm{C}-4 \mathrm{of} \mathrm{Ph}), 128.2(2 \mathrm{C})$, 122.2 (C-1 of $\mathrm{Ph}$ ), 110.3 (dioxolane $\mathrm{C}-2), 86.2(-\mathrm{C} \equiv), 85.8$ $(-\mathrm{C} \equiv$ ), 70.0 (dioxolane $\mathrm{C}-5$ ), 66.0 (dioxolane $\mathrm{C}-4$ ), 26.2 and $26.0\left(\mathrm{CMe}_{2}\right)$ [good agreement of $\delta_{\mathrm{H}}$ and $\delta_{\mathrm{C}}$ with lit. ${ }^{27}$ ]. Acetone $(20 \%) ; \delta_{\mathrm{H}} 2.17 ; \delta_{\mathrm{C}} 207.0$ and 30.9 , was also present.

FVP of ylide $16(107 \mathrm{mg})$ at $750{ }^{\circ} \mathrm{C}$ gave at the furnace exit a 3:1 mixture of $\mathrm{Ph}_{3} \mathrm{PO} ; \delta_{\mathrm{P}}+29.2$ and $\mathrm{Ph}_{3} \mathrm{P} ; \delta_{\mathrm{P}}-5.5$, and in the cold trap a mixture of 29 (data as above), acetone, and:

2-Phenyloxete 30 (Found 133.0649. $\mathrm{C}_{9} \mathrm{H}_{9} \mathrm{O}(\mathrm{M}+\mathrm{H})$ requires 133.0653); $\delta_{\mathrm{H}}(300 \mathrm{MHz}) 6.16(1 \mathrm{H}, \mathrm{t}, J 6.9)$ and $5.14(2 \mathrm{H}, \mathrm{d}$, $J$ 6.9); $\delta_{\mathrm{C}}(75 \mathrm{MHz}) 93.9(\mathrm{CH})$ and $78.7\left(\mathrm{CH}_{2}\right)$. Due to peak overlap the phenyl and quaternary $=\mathrm{C}$ - signals could not be observed with certainty.

FVP of ylide $9(70 \mathrm{mg})$ at $500{ }^{\circ} \mathrm{C}$ gave at the furnace exit $\mathrm{Ph}_{3} \mathrm{PO} ; \delta_{\mathrm{P}}+29.2$ and in the cold trap a mixture of:

1-(Tetrahydrofuran-2-yl)but-2-yn-1-one $37 \quad(26 \%) ; \quad \delta_{\mathrm{H}}$ (400 MHz) 4.44 (1 H, dd, $J$ 8.6, 5.8), 3.95-3.80 (2 H, m), 2.30-2.00 (4 H, m) and $2.07(3 \mathrm{H}, \mathrm{s}) ; \delta_{\mathrm{C}}(75 \mathrm{MHz}) 188.8(\mathrm{CO})$, $93.7(\mathrm{C},-\mathrm{C} \equiv), 83.7(\mathrm{CH}), 78.3(\mathrm{C},-\mathrm{C} \equiv), 69.6\left(\mathrm{CH}_{2}\right), 29.3$ $\left(\mathrm{CH}_{2}\right), 25.25\left(\mathrm{CH}_{2}\right)$ and $4.3\left(\mathrm{CH}_{3}\right)$ and 4-(tetrahydrofuran-2-yl) but-3-yn-2-one $39(58 \%) ; \delta_{\mathrm{H}}(400 \mathrm{MHz}) 4.74(1 \mathrm{H}$, dd, $J$ 8.0, 4.8), 4.1-3.9 (2 H, m), 2.2-1.8 (4 H, m) and $2.35(3 \mathrm{H}, \mathrm{s}) ; \delta_{\mathrm{C}}$ (75 MHz) 184.3 (CO), $91.0(\mathrm{C},-\mathrm{C} \equiv)$, $83.5(\mathrm{C},-\mathrm{C} \equiv)$, $68.3\left(\mathrm{CH}_{2}\right)$, $67.6(\mathrm{CH}), 32.7\left(\mathrm{CH}_{2}\right), 32.6\left(\mathrm{CH}_{3}\right)$ and $25.34\left(\mathrm{CH}_{2}\right)$.

FVP of ylide $9(110 \mathrm{mg})$ at $700{ }^{\circ} \mathrm{C}$ gave at the furnace exit $\mathrm{Ph}_{3} \mathrm{PO} ; \delta_{\mathrm{P}}+29.2$ and in the cold trap a mixture of $37(18 \%), 39$ $(33 \%)$ data as above, and:
3-Acetylfuran 41 (17\%); $\delta_{\mathrm{H}}(300 \mathrm{MHz}) 8.03(1 \mathrm{H}$, dd, $J 1.5$, 0.9), 7.45 (1 H, dd, J 2.0, 1.5), 6.77 (1 H, dd, $J 2.0,0.9$ ) and 2.45 $(3 \mathrm{H}, \mathrm{s}) ; \delta_{\mathrm{C}}(75 \mathrm{MHz}) 192.6(\mathrm{CO}), 147.5(\mathrm{CH}), 144.2(\mathrm{CH}), 128.0$ (C), $108.5(\mathrm{CH})$ and $27.8\left(\mathrm{CH}_{3}\right)$ [good agreement of $\delta_{\mathrm{H}}$ and $\delta_{\mathrm{C}}$ with lit. $\left.{ }^{36}\right]$.

FVP of ylide $10(70 \mathrm{mg})$ at $500{ }^{\circ} \mathrm{C}$ gave at the furnace exit $\mathrm{Ph}_{3} \mathrm{PO} ; \delta_{\mathrm{P}}+29.2$ and in the cold trap:

A mixture of 3-phenyl-1-(tetrahydrofuran-2-yl)prop-2-yn-1one $38(29 \%) ; \delta_{\mathrm{H}}(300 \mathrm{MHz}) 7.65-7.35(5 \mathrm{H}, \mathrm{m}), 4.58(1 \mathrm{H}$, $\mathrm{dd}, J$ 8.7, 5.7), 4.14-3.85 (2 H, m) and 2.40-1.90 (4 H, m); $\delta_{\mathrm{C}}(75 \mathrm{MHz}) 83.9(\mathrm{CH}), 69.8\left(\mathrm{CH}_{2}\right), 29.7\left(\mathrm{CH}_{2}\right)$ and $25.4\left(\mathrm{CH}_{2}\right)$ [due to low intensity and peak overlap, the signals for $\mathrm{CO}$, $-\mathrm{C} \equiv$ and $\mathrm{Ph}$ could not be assigned with certainty] and 1-phenyl-3-(tetrahydrofuran-2-yl)prop-2-yn-1-one $40 \quad(30 \%)$; $\delta_{\mathrm{H}}(300 \mathrm{MHz}) 7.65-7.35(5 \mathrm{H}, \mathrm{m}), 4.89$ (1 H, dd, $J$ 7.8, 4.8), 4.14-3.85 (2 H, m) and 2.40-1.90 (4 H, m); $\delta_{\mathrm{C}}(75 \mathrm{MHz})$ $68.4\left(\mathrm{CH}_{2}\right), 67.9(\mathrm{CH}), 32.9\left(\mathrm{CH}_{2}\right)$ and $25.4\left(\mathrm{CH}_{2}\right)$ [due to low intensity and peak overlap, the signals for $\mathrm{CO},-\mathrm{C} \equiv$ and $\mathrm{Ph}$ could not be assigned with certainty]. Aromatic $\mathrm{CH}$ signals for 38 and 40 were at 134.2, 133.2, 130.9, 129.6, 128.63 and 12858.

FVP of ylide $10(50 \mathrm{mg})$ at $700{ }^{\circ} \mathrm{C}$ gave at the furnace exit $\mathrm{Ph}_{3} \mathrm{PO} ; \delta_{\mathrm{P}}+29.2$ and in the cold trap a mixture of $38(12 \%), 40$ (14\%) data as above, and:

3-Benzoylfuran $42(37 \%) ; \delta_{\mathrm{H}}(300 \mathrm{MHz}) 7.93$ (1 H, dd, $J 1.5$, 0.9), 7.87-7.82 (2 H, m), 7.62-7.56 (1 H, m), 7.51 (1 H, dd, $J 1.8,1.5), 7.50-7.46(2 \mathrm{H}, \mathrm{m})$ and $6.92(1 \mathrm{H}, \mathrm{dd}, J 1.8,0.9)$ [good agreement of $\delta_{\mathrm{H}}$ with lit. ${ }^{37}$ ].

FVP of ylide $11(120 \mathrm{mg})$ at $500{ }^{\circ} \mathrm{C}$ gave at the furnace exit $\mathrm{Ph}_{3} \mathrm{PO} ; \delta_{\mathrm{P}}+29.2$ and in the cold trap a mixture of:

Ethyl 3-(tetrahydrofuran-2-yl)propynoate 45 (42\%) (Found 167.0703. $\mathrm{C}_{9} \mathrm{H}_{11} \mathrm{O}_{3}(\mathrm{M}-\mathrm{H})$ requires 167.0708); $\nu_{\max } / \mathrm{cm}^{-1} 2239$ $(\mathrm{C} \equiv \mathrm{C}), 1717,1368,1254,1052 ， 1031 ， 860$ and $752 ; \delta_{\mathrm{H}}$ (400 MHz) 4.73 (1 H, dd, $J$ 8.0, 4.0, 2-H), 4.23 (2 H, q, $J$ 7.0), 3.99-3.92 (1 H, m, 5-H), 3.89-3.80 (1 H, m, 5-H), 2.30-2.20 (1 H, m, 4-H), 2.20-2.00 (2 H, m), 2.00-1.85 (1 H, m) and 1.31 (3 H, t, $J$ 7.0); $\delta_{\mathrm{C}}(100 \mathrm{MHz}) 153.3(\mathrm{CO}), 86.9(\mathrm{C},-\mathrm{C} \equiv), 76.1$ $(\mathrm{C},-\mathrm{C} \equiv), 68.3\left(\mathrm{CH}_{2}\right), 67.5(\mathrm{CH}), 62.0\left(\mathrm{CH}_{2}\right), 32.7\left(\mathrm{CH}_{2}\right), 25.3$ $\left(\mathrm{CH}_{2}\right)$ and $13.9\left(\mathrm{CH}_{3}\right)$ and 2-ethynyltetrahydrofuran 18 (16\%), data as for FVP of 6.

FVP of ylide $11(120 \mathrm{mg})$ at $750{ }^{\circ} \mathrm{C}$ gave at the furnace exit $\mathrm{Ph}_{3} \mathrm{PO}: \delta_{\mathrm{P}}+29.2$ and in the cold trap a mixture containing low yields of furan, cyclopentadiene and acetaldehyde.

FVP of ylide $15(100 \mathrm{mg})$ at $500{ }^{\circ} \mathrm{C}$ gave at the furnace exit $\mathrm{Ph}_{3} \mathrm{PO} ; \delta_{\mathrm{P}}+29.2$ and in the cold trap:

Ethyl 3-(tetrahydropyran-4-yl)propynoate 46 (60\%) (Found 205.0830. $\mathrm{C}_{10} \mathrm{H}_{14} \mathrm{O}_{3} \mathrm{Na}(\mathrm{M}+\mathrm{Na})$ requires 205.0841); $\nu_{\max } / \mathrm{cm}^{-1}$ $2239(\mathrm{C} \equiv \mathrm{C}), 1712,1260,1250,1095,1021$ and $747 ; \delta_{\mathrm{H}}$ (500 MHz) 4.23 (2 H, q, J 7.0), 3.90 (2 H, ddd, J 11.6, 5.6, 3.6, 2,6-H), 3.51 (2 H, ddd, J 11.8, 8.8, 3.0, 2,6-H), 2.81-2.75 (1 H, m, 4-H), 1.91-1.84 (2 H, m, 3,5-H), 1.79-1.71 (2 H, m, 3,5-H) and $1.32\left(3 \mathrm{H}, \mathrm{t}, J\right.$ 7.0); $\delta_{\mathrm{C}}(125 \mathrm{MHz}) 153.8(\mathrm{CO}), 90.3(\mathrm{C},-\mathrm{C} \equiv)$, $73.8(\mathrm{C},-\mathrm{C} \equiv), 66.1\left(\mathrm{CH}_{2}\right), 62.0\left(\mathrm{CH}_{2}\right), 31.0\left(\mathrm{CH}_{2}\right), 26.1(\mathrm{CH})$ and $14.0\left(\mathrm{CH}_{3}\right)$.

FVP of ylide $15(100 \mathrm{mg})$ at $750{ }^{\circ} \mathrm{C}$ gave at the furnace exit $\mathrm{Ph}_{3} \mathrm{PO} ; \delta_{\mathrm{P}}+29.2$ and in the cold trap 4-ethynyltetrahydropyran 
$19(30 \%)$ together with cyclopentadiene (20\%) and acetaldehyde (25\%); data as for FVP of $\mathbf{1 2 .}$

FVP of ylide $17(130 \mathrm{mg})$ at $600{ }^{\circ} \mathrm{C}$ gave at the furnace exit $\mathrm{Ph}_{3} \mathrm{PO} ; \delta_{\mathrm{P}}+29.2$ and in the cold trap:

A mixture of ethyl 3-(2,2-dimethyl-1,3-dioxolan-4-yl)propynoate $47(68 \%)$ (Found 221.0782. $\mathrm{C}_{10} \mathrm{H}_{14} \mathrm{O}_{4} \mathrm{Na}(\mathrm{M}+\mathrm{Na})$ requires 221.0790); $\nu_{\max } / \mathrm{cm}^{-1} 2244(\mathrm{C} \equiv \mathrm{C}), 1716(\mathrm{C}=\mathrm{O}), 1374$, 1248, 1067 and 846; $\delta_{\mathrm{H}}(300 \mathrm{MHz}) 4.82(1 \mathrm{H}$, dd, $J$ 6.6, 5.6, 4H), 4.24 (2 H, q, J 7.2), 4.21 (1 H, dd, J 8.4, 6.6, 5-H), 4.05 (1 H, $\mathrm{dd}, J$ 8.4, 5.6, 5-H), 1.50 (3 H, q, $J 0.6), 1.39$ (3 H, q, $J 0.6)$ and $1.31\left(3 \mathrm{H}, \mathrm{t}, J\right.$ 7.2); $\delta_{\mathrm{C}}(75 \mathrm{MHz}) 153.0$ (CO), 111.2 (dioxolane

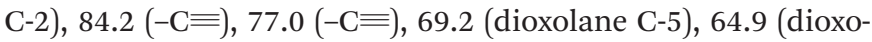
lane C-4), $62.2\left(\mathrm{CH}_{2} \mathrm{CH}_{3}\right), 26.0$ and $25.7\left(\mathrm{CMe}_{2}\right)$ and 13.9 $\left(\mathrm{CH}_{2} \mathrm{CH}_{3}\right)$ and 4-ethynyl-2,2-dimethyl-1,3-dioxolane 48 (9\%) (Found 125.0602. $\mathrm{C}_{7} \mathrm{H}_{9} \mathrm{O}_{2}(\mathrm{M}-\mathrm{H})$ requires 125.0603); $\delta_{\mathrm{H}}$ (300 MHz) 4.72 (1 H, td, $J$ 6.3, 2.1, 4-H), 4.18 (1 H, dd, $J$ 8.1, 6.3, 5-H), 3.95 (1 H, dd, $J$ 8.1, 6.3, 5-H), 2.51 (1 H, d, $J$ 2.1, $\equiv \mathrm{CH}), 1.50$ (3 H, q, $J 0.6)$ and 1.39 ( $3 \mathrm{H}, \mathrm{q}, J 0.6) ; \delta_{\mathrm{C}}(75 \mathrm{MHz})$ 110.5 (dioxolane $\mathrm{C}-2)$, $85.4(-\mathrm{C} \equiv), 73.9(\mathrm{HC} \equiv), 69.8$ (dioxolane C-5), 65.2 (dioxolane C-4), 26.1 and $25.8\left(\mathrm{CMe}_{2}\right)$.

FVP of ylide $17(120 \mathrm{mg})$ at $650{ }^{\circ} \mathrm{C}$ gave at the furnace exit $\mathrm{Ph}_{3} \mathrm{PO} ; \delta_{\mathrm{P}}+29.2$ and in the cold trap a mixture of $47(39 \%)$ and 48 (30\%), data as above.

\section{Conclusions}

Our results show that the tetrahydrofuran, tetrahydropyran and 2,2-dimethyl-1,3-dioxolane rings are generally stable under the conditions required for alkyne formation using the FVP of stabilised phosphonium ylides. Increasing the pyrolysis temperature does lead to observation of new, largely carbenebased, processes in some cases but provided the temperature is carefully controlled the use of this method to construct acetylenic carbohydrate derivatives should be possible and further results on this will be reported shortly.

\section{Notes and references}

1 R. A. Aitken and A. W. Thomas, in Chemistry of the functional groups, Supplement A3, ed. S. Patai, Wiley, New York, 1997, pp. 473-536.

2 S. Trippett and D. M. Walker, J. Chem. Soc., 1959, 38743876.

3 G. Märkl, Chem. Ber., 1961, 94, 3005-3010.

4 A. W. Johnson, in Ylides and Imines of Phosphorus, Wiley, New York, 1993, pp. 129-151.

5 R. A. Aitken and J. I. Atherton, J. Chem. Soc., Chem. Commun., 1985, 1140-1141.

6 R. A. Aitken and A. N. Garnett, New J. Chem., 2009, 33, 2402-2404.

7 R. A. Aitken and L. Murray, J. Org. Chem., 2008, 73, 97819783.

8 R. A. Aitken, N. Karodia, T. Massil and R. J. Young, J. Chem. Soc., Perkin Trans. 1, 2002, 533-541.
9 R. A. Aitken and Y. Boubalouta, in Advances in Heterocyclic Chemistry, ed. E. F. V. Scriven and C. A. Ramsden, Elsevier, Oxford, 2015, ch. 2, vol. 115, pp. 93-150.

10 E. J. Horn and J. Gervay-Hague, J. Org. Chem., 2009, 74, 4357-4359.

11 J. M. J. Tronchet, A. P. Bonenfant, F. Perret, A. Gonzalez, J.-B. Zumwald, E. M. Martinez and B. Bachler, Helv. Chim. Acta, 1980, 63, 1181-1189.

12 R. M. Adlington, J. E. Baldwin, G. J. Pritchard and K. C. Spencer, Tetrahedron Lett., 2000, 41, 575-578.

13 D. E. Bays, R. P. C. Cousins, H. J. Dyke, C. D. Eldred, B. D. Judkins, M. Pass and A. M. K. Pennell, US Pat, 6492348 B1, 2002.

14 P. Nakache, E. Ghera and A. Hassner, Tetrahedron Lett., 2000, 41, 5583-5587.

15 K. Fujiwara, Y. Hirose, D. Sato, H. Kawai and T. Suzuki, Tetrahedron Lett., 2010, 51, 4263-4266.

16 R. S. Vartanyan, Zh. V. Kazaryan and S. A. Vartanyan, Chem. Heterocycl. Compd. (Engl. Transl.), 1979, 253-254.

17 H. J. Bestmann, Chem. Ber., 1962, 95, 58-63.

18 S. T. D. Gough and S. Trippett, J. Chem. Soc., 1964, 543544.

19 C. R. Schmid and J. D. Bryant, Org. Synth., 1995, 72, 6-9; C. R. Schmid and J. D. Bryant, Org. Synth. Coll. Vol., 1998, 9, 450-453.

20 M. J. Earle, A. Abdur-Rashid and N. D. Priestley, J. Org. Chem., 1996, 61, 5697-5700.

21 R. A. Aitken, N. Karodia and P. Lightfoot, J. Chem. Soc., Perkin Trans. 2, 2000, 333-340.

22 R. A. Aitken and J. I. Atherton, J. Chem. Soc., Perkin Trans. 1, 1994, 1281.

23 R. F. C. Brown, Recl. Trav. Chim. Pays-Bas, 1988, 107, 655661.

24 R. A. Aitken, I. M. Fairhurst, A. Ford, P. E. Y. Milne, D. W. Russell and M. Whittaker, J. Chem. Soc., Chem. Commun., 1993, 1517-1519.

25 R. A. Aitken, I. M. Fairhurst, A. Ford, P. E. Y. Milne, D. W. Russell and M. Whittaker, J. Chem. Soc., Perkin Trans. 1, 1997, 3107-3112.

26 R. R. Da Silva, V. G. Toscano and R. G. Weiss, J. Chem. Soc., Chem. Commun., 1973, 567-568.

27 D. S. Brown, M. Bruno, R. J. Davenport and S. V. Ley, Tetrahedron, 1989, 45, 4293-4308.

28 A. R. Katritzky, S. Rachwal and B. Rachwal, J. Chem. Soc., Perkin Trans. 1, 1990, 1717-1725.

29 W. Shen and L. Wang, J. Org. Chem., 1999, 64, 8873-8879.

30 T. Otsuki, Bull. Chem. Soc. Jpn., 1974, 47, 3089-3093.

31 B. Alcaide, P. Almendros, T. Martínez del Campo and I. Fernández, Chem. Commun., 2011, 47, 9054-9056.

32 K. Aikawa, Y. Hioki, N. Shimizu and K. Mikami, J. Am. Chem. Soc., 2011, 133, 20092-20095.

33 P. C. Martino and P. B. Shevlin, J. Am. Chem. Soc., 1980, 102, 5429-5430.

34 P. A. Chopard, R. J. G. Searle and F. H. Devitt, J. Org. Chem., 1965, 30, 1015-1019.

35 Y. Shen, W. Cen and Y. Huang, Synthesis, 1985, 159-160. 
36 C. Gryparis, I. N. Lykakis, C. Efe, I.-P. Zaravinos, T. Vidali, E. Kladou and M. Stratakis, Org. Biomol. Chem., 2011, 9, 5655-5658.

37 T. Satoh, T. Itaya, K. Okuro, M. Miura and M. Nomura, J. Org. Chem., 1995, 60, 7267-7271.
38 R. A. Aitken, C. E. R. Horsburgh, J. G. McCreadie and S. Seth, J. Chem. Soc., Perkin Trans. 1, 1994, 1727-1732.

39 R. A. Aitken and J. J. Morrison, ARKIVOC, 2008, (x), 103-112.

40 M. Apparu and J. K. Crandall, J. Org. Chem., 1984, 49, 2125-2130. 